OPEN ACCESS

Edited by:

Consolato Sergi,

University of Alberta Hospital, Canada

Reviewed by:

Zheng Quan Toh,

Royal Children's Hospital, Australia

Moftah Hussin Alhagamhmad,

Al-Arab Medical University, Libya

${ }^{*}$ Correspondence:

Licia Pensabene

pensabene@unicz.it

tThese authors have contributed equally to this work

¥Present address:

Ettore Stefanelli,

Pediatric Unit, Latisana Hospital, Azienda Sanitaria Universitaria Friuli

Centrale, Udine, Italy

Specialty section:

This article was submitted to

Pediatric Gastroenterology,

Hepatology and Nutrition,

a section of the journal

Frontiers in Pediatrics

Received: 16 July 2020 Accepted: 23 November 2020

Published: 22 December 2020

Citation:

Sestito S, D'Auria E, Baldassarre ME, Salvatore S, Tallarico V, Stefanelli E,

Tarsitano F, Concolino D and Pensabene L (2020) The Role of

Prebiotics and Probiotics in Prevention of Allergic Diseases in Infants. Front. Pediatr. 8:583946. doi: 10.3389/fped.2020.583946

\section{The Role of Prebiotics and Probiotics in Prevention of Allergic Diseases in Infants}

\author{
Simona Sestito ${ }^{1 \dagger}$, Enza D'Auria ${ }^{2 t}$, Maria Elisabetta Baldassarre ${ }^{3}$, Silvia Salvatore ${ }^{4}$, \\ Valeria Tallarico ${ }^{1}$, Ettore Stefanelli ${ }^{1 \neq}$, Flora Tarsitano ${ }^{1}$, Daniela Concolino ${ }^{1,5}$ and \\ Licia Pensabene ${ }^{1 *}$ \\ ${ }^{1}$ Pediatric Unit, Department of Medical and Surgical Sciences, University "Magna Graecia" of Catanzaro, Catanzaro, Italy, \\ ${ }^{2}$ Department of Pediatrics, Vittore Buzzi Children's Hospital-University of Milan, Milan, Italy, ${ }^{3}$ Neonatology and Neonatal \\ Intensive Care Unit, Department of Biomedical Science and Human Oncology, "Aldo Moro" University of Bari, Bari, Italy, \\ ${ }^{4}$ Department of Pediatrics, Ospedale "F. Del Ponte", University of Insubria, Varese, Italy, ${ }^{5}$ Department of Health Sciences, \\ School of Medicine and Surgery, University Magna Graecia of Catanzaro, Catanzaro, Italy
}

Allergic diseases have been linked to genetic and/or environmental factors, such as antibiotic use, westernized high fat and low fiber diet, which lead to early intestinal dysbiosis, and account for the rise in allergy prevalence, especially in western countries. Allergic diseases have shown reduced microbial diversity, including fewer lactobacilli and bifidobacteria, within the neonatal microbiota, before the onset of atopic diseases. Raised interest in microbiota manipulating strategies to restore the microbial balance for atopic disease prevention, through prebiotics, probiotics, or synbiotics supplementation, has been reported. We reviewed and discussed the role of prebiotics and/or probiotics supplementation for allergy prevention in infants. We searched PubMed and the Cochrane Database using keywords relating to "allergy" OR "allergic disorders," "prevention" AND "prebiotics" OR "probiotics" OR "synbiotics." We limited our evaluation to papers of English language including children aged 0-2 years old. Different products or strains used, different period of intervention, duration of supplementation, has hampered the draw of definitive conclusions on the clinical impact of probiotics and/or prebiotics for prevention of allergic diseases in infants, except for atopic dermatitis in infants at high-risk. This preventive effect on eczema in high-risk infants is supported by clear evidence for probiotics but only moderate evidence for prebiotic supplementation. However, the optimal prebiotic or strain of probiotic, dose, duration, and timing of intervention remains uncertain. Particularly, a combined pre- and post-natal intervention appeared of stronger benefit, although the definition of the optimal intervention starting time during gestation, the timing, and duration in the post-natal period, as well as the best target population, are still an unmet need.

\footnotetext{
Keywords: prebiotics, probiotics, prevention, atopic dermatitis, eczema, synbiotics, allergic diseases
} 


\section{INTRODUCTION}

Allergic diseases represent a medical challenge and a worldwide burden, in particular in the most developed countries, where the frequency of affected subjects overcome $30 \%$ and is still growing $(1,2)$. Allergic diseases are the result of a complex interaction genome-environment which leads to an alteration of the immune system $(3,4)$. A lot of genes, HLA, and specific genes identified by genome-wide association studies, have been identified for asthma $(5,6)$, food allergy (7), and atopic dermatitis $(8,9)$. In infants, allergic disease prevalence has been associated with the allergic status of the parents, being $\sim 10 \%$ in those with a negative family history of atopic disorders and $20-30 \%$ in those with allergy in their first-degree relatives (10). Although genetic factors can affect the tendency to the development of allergic diseases, the rapid rise of allergic diseases in the last two decades can be explained by environmental factors (11). A lot of factors related to the environment have been called in cause to explain the rise, especially in western countries. These include mode of delivery, with cesarean delivery representing a risk for atopy, food allergy and asthma (12), antibiotic use (13), westernized high fat and low fiber diet $(14,15)$, reduction of omega3-polyunsaturated fatty acids and vitamin D insufficiency or deficiency (16). All the above act on microbiota (Figure 1), which an increasing body of evidence suggests to play a central role in shaping the normal development, and maturation of the immune system (17). Some of the effects on immune programming are thought to be due to epigenetic effects on the expression of genes $(18,19)$.

In a healthy state, the gut microbiota is in eubiotic status; in contrast, gut dysbiosis, an imbalance in the composition and/or function of the gut microbiota, has been associated with allergic diseases, such as eczema, asthma, and food allergy (20-23). Animal and human studies have found that subjects with allergic disease are carriers of reduced microbial diversity and different proportions of certain microbial species (24).

The establishment of an altered gut microbiota seems to occur in the early stage of development, as demonstrated by studies that have shown that atopic infants vs. non-atopic infants at 1 year of age had different gut composition at 3 weeks of age and 3 months (25). These differences, with allergic diseases showing reduced microbial diversity, including fewer lactobacilli and bifidobacteria, were observed before the onset of clinical symptoms, supporting their possible causative role in allergic diseases $(24,26-28)$. In agreement with these observations, more recently West et al. (29) reported that the development of atopic eczema is influenced by lack of immune system modulation after birth, mediated by the gut microbiota. The majority of molecular data suggest that gut colonization occurs through contamination shortly after delivery $(30,31)$ although some recent experiments suggest that it might take places already in utero and then further shaped post-natally (32). Therefore, it has been speculated that the recent increase in the prevalence of allergy may be consequent to early intestinal dysbiosis (33). The above hypothesis and observations aroused the interest of research for shaping gut microbiota in the early stages to prevent the development of allergic diseases. Different strategies have been studied, including probiotic, prebiotic, synbiotic supplementation pre-natally, postnatally, or both (34).

Probiotics are "living microorganisms that, at certain doses, may provide health benefits" (10). Probiotics affect phagocytosis and synthesis of pro-inflammatory cytokines, and thus have been proposed as modulators of the allergic response and advocated as therapeutic and preventive interventions for allergic diseases $(35,36)$. Prebiotics are "non-digestible food components that selectively promote the growth of intestinal microbes with positive effects on host health" $(37,38)$, specifically stimulating the expansion of bifidobacteria and lactobacilli species (39). Altering the intake with foods of these components or supplementing the diet with prebiotics can modify in a positive manner the proportions and the activity of certain intestinal microbial species (39). Synbiotics are "combinations of prebiotics and probiotics" (40).

The aim of this narrative review was to provide researchers an updated overview on the use of prebiotics, probiotics, and synbiotics for the primary prevention of allergy in infants, highlighting the controversies, current research gaps, and potential developments in the field. This review considered the administration of probiotics as supplements, excluding the possible exposure through common food, naturally containing probiotics (such as fermented milk, yogurt). We searched the Cochrane library and PubMed, (Embase, Medline,) during the last 20 years, up to March 2020, using as keywords the following: "allergic diseases," "food allergy," "allergy prevention," "allergic proctocolitis," "atopic dermatitis," "wheezing," "eczema," "allergic rhinitis," "atopic disease," "prebiotics," "probiotics," "synbiotics," "prevention." We limited our evaluation by age ("children," "aged 0-2 years") and languages (English); however, to be more inclusive, the operators "AND" "OR" were also used. Intervention controlled trials, reviews, meta-analyses, and guidelines on prebiotics and probiotics were considered, as well as the following populations for possible supplementation with probiotics: pregnant women, breastfeeding mothers, and infants, regardless of exclusive breastfeeding. All types of prebiotics and probiotics and doses of supplementation were evaluated.

\section{MECHANISMS OF PROBIOTICS/PREBIOTICS IN MODULATING GUT MICROBIOTA}

Diet is recognized as one of the most important factors which may modulate the gut microbiota composition and function (41). It is well-known that changes in the composition of the diet, such as westernized high fat and low fiber diet, can modify the prevalence and types of intestinal microbial species, as certain species are more suitable to utilize specific substrates (42). An association between low-fiber diet and noncommunicable chronic diseases, including allergic diseases have been hypothesized on the basis of observational studies (43). The positive effects of the diet on gut microbiota are hypothesized to be due to the prebiotic component.

As anticipated, prebiotics "are non-digestible food components" that selectively trigger the growth in the gut 


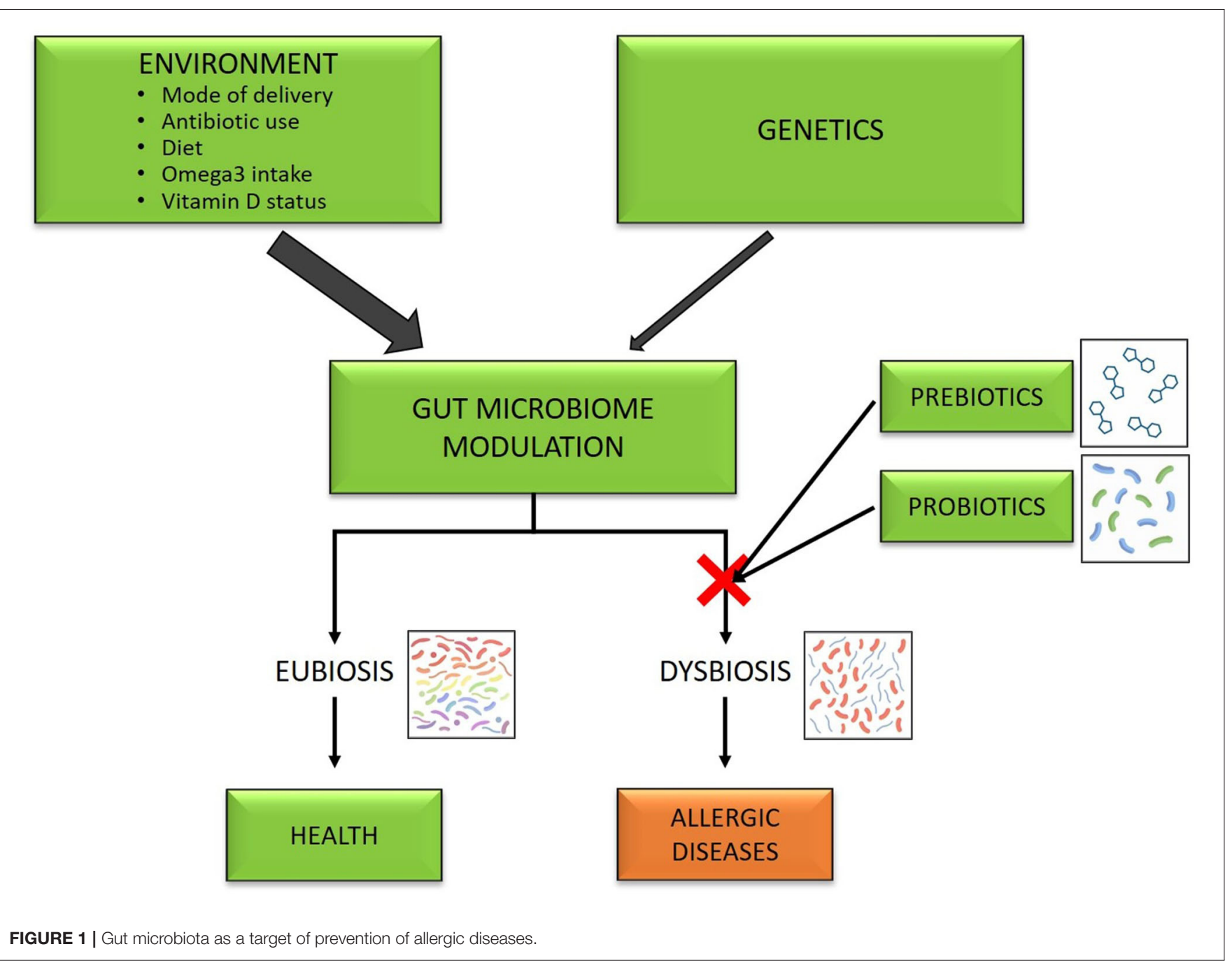

of microbes with positive effects for host health (38): not being the target of upper gastrointestinal digestive enzymes, they typically reach intact the colon, where they are fermented by intestinal microbes (main endproducts of their fermentation are short-chain fatty acids) and selectively stimulate the growth of those intestinal microorganisms (bifidobacteria and lactobacilli species) that are associated with host health and well-being (44). Indeed, they are the favorite meal of the saccharolytic bacteria living in the human gut, as different bacteria prefer other energy sources. Prebiotics are naturally contained in cereals, fruits, vegetables, etc. (non-digestible oligosaccharides), or can be produced by industry $(38,45)$. Consequently, by modifying the intake of foods containing these products or by supplementation with prebiotics, diet can be used as a powerful tool to direct the gut microbial population $(46,47)$.

Firstly, prebiotics are naturally present in human milk, who contains at least 200 human milk oligosaccharides (HMO), while oligosaccharides are virtually absent from cow's milk, which explains the increase of gut bifidobacteria observed in breastfed infants compared with standard formula-fed (SF) $(48,49)$.
Human milk oligosaccharides (among the widest components in human milk together with lactose and fats), may represent an excellent meal for beneficial species and prevent the adhesion of pathogens, contributing to the shift of the infant gut microbiota, influencing the immune system (50) and infants health (51). Different HMOs have different properties and functions (52); their molecular structure differs in size and sequence among women (53), being influenced by certain factors (lactation period, secretor status, maternal Lewis Blood Group, etc.), and giving the infant a different degree of protection. A recent study showed infants receiving human milk with a low Lacto- $\mathrm{N}$-fucopentaose III (LNFP) content were more prone to develop Cow's Milk allergy (CMA) compared to infants fed with milk containing a high concentration of LNFP III (OR: 6.7, 95\% CI 2.0-22) (54). However, the role of breastfeeding $(\mathrm{BF})$ in preventing allergic diseases is still debated (55), with studies showing no protective effect or even an increased risk for $\mathrm{AD}$ with prolonged exclusive breastfeeding (40,56-58), while other studies/systematic reviews reporting positive effects on prevention, mostly of $\operatorname{AD}(39,59)$. From a mechanistic point of view, BF is thought to prevent 
allergy development through its content of allergens and immune mediators, absent in artificial milk $(55,60)$, as well as of HMOs known to stimulate a gut microbiota that might induce tolerance (61). Consequently, when breastfeeding is not possible, trying to reproduce the functional effects of HMOs, infant formulas have been supplemented with galactooligosaccharides and/or fructooligosaccharides. Studies in term and preterm infants indicate that a short-chain galacto-oligosaccharides (scGOS)/long-chain fructo-oligosaccharides (lcFOS) mixture has prebiotic activities, producing a gut microbiota similar to that of breastfed infants (62-64).

Moreover, in murine models, galacto-oligosaccharides (GOS) have been shown to improve the skin lesions of atopic dermatitis, by inducing the production of IL-10 and blocking the production of pro-inflammatory cytokines, such as IL-17, (65). In addition, prebiotics were reported to decrease Ig free light chain (Ig-fLC) concentrations in infants at high-risk for allergies (66): Ig-fLC might play a role in the pathophysiology of the allergic disease since increased Ig-fLC content was found in patients with $\mathrm{AD}$, allergic rhinitis, asthma or cow's milk allergy. However, overall, the mechanism of action of prebiotics seems mostly due to the previously described indirect effects on gut microbiota.

Another approach used for shaping gut microbiota is the supplementation of the diet with probiotics. Among ligands for "pattern recognition receptors," Toll-like receptors (TLRs), able to activate the immune system, such as virus and the recently identified virus-derived synthetic RNA-DNA hybrids, Bacteria are considered the most powerful immunomodulating factors (39).

The possible mechanism of action of probiotics in this regard includes influences on the maturation of intestinal barrier and on immune response by rebalancing Th1 and Th2 response while suppressing Th17 cells, promoting Tolerogenic Dendritic and Regulatory $\mathrm{T}$ (Treg) cell development, and pattern recognition receptor (TLR) stimulation (67). In fact, dendritic cells within the gut mucosa play a key role in the differentiation of regulatory $\mathrm{T}$ cells (Treg) which are known to be important in the development of immune tolerance (68). Alterations in Treg functions are associated with the development of allergic diseases (69) and evidence indicates that the gut microbiota acquired early in life is essential for the right development of Treg and Th1/th2 balance (70). The possible mechanisms whereby probiotics may obtain atopy prevention include the stimulation of Th1 response and a decrease in the secretion of Th2 cytokines, such as interleukin (IL)-4, IL-5, and IL-13, a decrease in IgE, and a rise of C-reactive protein and IgA (41). In addition, a murine model of asthma showed that neonatal supplementation with probiotics inhibits the development of allergic sensitization and airway disease by inducing regulatory $\mathrm{T}$ cells (Tregs) and producing transforming growth factor-B (71).

Indeed, selected strain of probiotics (such as Lactobacillus GG) provides maturational signals for the gut-associated lymphoid tissues (GALT) and development of Tolerogenic dendritic and regulatory $\mathrm{T}$ (Treg) cell differentiation, which will induce intestinal barrier maturation and reduce the prevalence of the allergic reactions (72). Therefore, by improving the barrier function and reducing the leakage of antigens through the mucosa probiotics may reduce the potential exposure to allergens (73). Moreover, specific probiotics demonstrated local and systemic anti-inflammatory effects referred to increased secretion of IL-10 (67). Other researchers suggested as a possible mechanism of action of probiotics, in regard to protection against allergic diseases, also the stimulation of Toll-like receptors, which induce the production of mediators, e.g., IL-6, and further IgA secretion (74).

In addition, through increased production of secretory IgA, which contributes to the exclusion of antigens from the intestinal mucosa (75) probiotics may obtain direct modulation of the immune system and eventually prevention of allergic diseases (76).

Moreover, colonizing the mother pre-natally by probiotics supplementation, together with subsequent changes in her breast milk composition and cytokines pattern, with an increased concentration of transforming growth factor-beta (TGF-b), could be beneficial for the infant regarding allergy development (77) and acquisition of immunotolerance (78).

In summary, the probiotics could potentially produce local effects, such as permeability reduction and thus systemic antigens penetration, increased local IgA production, and tolerance induction. Moreover, anti-inflammatory effects mediated by Toll-like receptors, the stimulation of Th1 response to allergens, the activation of tolerogenic dendritic cells, and the production of Treg are among the systemic effects of probiotics $(75,79)$.

However, despite the evidence on possible mechanisms of action of different preventive strategies, studies evaluating the efficacy of prebiotic and/or probiotic supplementation in the prevention of allergic diseases have yielded conflicting results.

\section{PREBIOTICS TO PREVENT ALLERGIC DISEASES}

The bifidogenic effect of human milk (rich in oligosaccharides) is well-known. Prebiotics have long been added to infant milk formulas to mimic these functional characteristics of breast milk $(52,80,81)$. A combination of galacto-oligosaccharide (GOS) and fructo-oligosaccharide (FOS) (scGOS 90\% plus lcFOS 10\%) was prebiotic of choice in a number of intervention trials. Acidic oligosaccharides (AOS), polydextrose (PDX) (with or without lactulose), different content of lactose, oligofructose plus inulin have also been tested (Table 1). Modification of intestinal microbiota represents the principal way by which this effect has been orchestrated (93) and has been reported in several studies $(82,90,92,94,95)$. The $2^{\prime}$-fucosyllactose $\left(2^{\prime}\right.$-FL) human milk oligosaccharide (HMO), the most plentiful HMO in most human milk, has been recently synthesized and is now commercially available in few supplemented infant formulas, bringing the composition closer to human milk (95).

We summarize the evidence on the preventive effects of different prebiotic administration in Table 1. The majority of these studies evaluated the effects of prebiotics on atopic dermatitis (AD); other allergic manifestations were much less investigated; however, it remains unclear whether prebiotics supplementation can prevent allergic diseases 
TABLE 1 | Prebiotics administration in prevention of allergic disorders.

(A) Prebiotic + Standard formula (or prebiotic of human milk).

\begin{tabular}{|c|c|c|c|c|c|c|}
\hline References & Study & Enrolled patients & $\begin{array}{l}\text { Prebiotic }+ \text { Standard formula (or } \\
\text { prebiotic of human milk) }\end{array}$ & $\begin{array}{l}\text { Prebiotic } \\
\text { substance, } \\
\text { Beginning of } \\
\text { treatment (S), } \\
\text { End of treatment } \\
\text { (E). }\end{array}$ & Outcomes & Follow-up (duration) \\
\hline $\begin{array}{l}\text { Ziegler et al. } \\
\text { (82) }\end{array}$ & $\begin{array}{l}\text { double-blind, } \\
\text { randomized, } \\
\text { controlled, } \\
\text { parallel-group, } \\
\text { prospective trial }\end{array}$ & $\begin{array}{l}226 \text { healthy term infants in } 3 \\
\text { groups: } \\
\text { - } 58 \text { in control group: control } \\
\quad \text { formula only } \\
-58 \text { in PG4 group: control formula } \\
+4 \mathrm{~g} / \mathrm{L} \text { prebiotic mixture } \\
-48 \text { in PGL8 group: control formula } \\
+8 \mathrm{~g} / \mathrm{L} \text { prebiotic mixture }\end{array}$ & $\begin{array}{l}\text { Control formula added with a prebiotic } \\
\text { mixture ( } 4 \mathrm{~g} / \mathrm{L}) \text { of PDX and GOS, } 50: 50 \\
\text { ratio (PG4 group) } \\
\text { Control formula containing a prebiotic } \\
\text { mixture ( } 8 \mathrm{~g} / \mathrm{L}) \text { of PDX, GOS, and LOS, } \\
\text { 50:33:17 ratio). (PGL8 group) }\end{array}$ & $\begin{array}{l}\text { S: } 14 \text { days of age } \\
\text { E: } 120 \text { days of age }\end{array}$ & $\begin{array}{l}\text { Infants fed formula containing a prebiotic } \\
\text { mixture achieved normal growth and stool } \\
\text { characteristics more similar to those of } \\
\text { breast-fed infants (softer, looser) compared to } \\
\text { infants fed an unsupplemented formula. } \\
\text { Statistical difference among adverse events: } \\
\text { - Eczema (PG4 vs. control: } 18 \text { vs. } 7 \%, P= \\
\text { 0.046; PG4 vs. PGL8: } 18 \text { vs. } 4 \%, P=0.008 \text { ) } \\
\text { - Diarrhea: control vs. PG4: } 4 \text { vs. } 18 \%, P= \\
\text { 0.008) } \\
\text { - Irritability: control vs. PGL8, } 4 \text { vs. } 16 \%, P \\
=0.027 \text { ) }\end{array}$ & 120 days \\
\hline $\begin{array}{l}\text { Niele et al. } \\
(83)\end{array}$ & $\begin{array}{l}\text { Double-blind, } \\
\text { randomized placebo } \\
\text { controlled trial }\end{array}$ & $\begin{array}{l}113 \text { preterm infants ( } G A<32 \text { weeks } \\
\text { or Wt }<1.500 \text { gr) } \\
94 / 98 \text { infants eligible at the } \\
\text { corrected age of } 1 \text { year participated } \\
\text { in the follow-up study }\end{array}$ & $\begin{array}{l}\text { Prebiotic mixture: } 80 \% \text { scGOS/ICFOS and } \\
20 \% \text { pAOS } \\
\text { Placebo mixture: maltodextrin in } \\
\text { increasing dose for } 30 \text { days. } \\
\text { After discharge, all infants received Human } \\
\text { Milk or Nenatal } \\
\text { Start or Nenatal } 1 \text { (both without } \\
\text { oligosaccharides or probiotics) }\end{array}$ & $\begin{array}{l}\text { S: }<3 \text { days of life } \\
\text { E: } 30 \text { days of life }\end{array}$ & $\begin{array}{l}\text { Supplementation with non-human neutral and } \\
\text { acidic oligosaccharides during the neonatal } \\
\text { period in preterm infants did } \\
\text { not significantly decrease the incidence of } \\
\text { allergic and infectious diseases during the 1st } \\
\text { year of life (AD at } 1 \text { year: } 15 \text { vs. 19\%) }\end{array}$ & 12 months \\
\hline $\begin{array}{l}\text { Gruber et al. } \\
\text { (84) }\end{array}$ & $\begin{array}{l}\text { double-blind, } \\
\text { placebo-controlled, } \\
\text { randomized } \\
\text { prospective } \\
\text { nutritional } \\
\text { intervention study }\end{array}$ & $\begin{array}{l}\text { Healthy term infants with } \\
\text { low atopy risk: } \\
-414 \text { infants in prebiotic group (PG) } \\
-416 \text { infants in control group (CG). } \\
\text { - } 300 \text { infants in breast-feeding } \\
\text { group (BG) }\end{array}$ & $\begin{array}{l}\text { PG: regular formula containing a specific } \\
\text { mixture of neutral oligosaccharides } \\
\text { [scGOS/lcFOS, ratio 9:1, (85 wt\%),] and } \\
\text { pectin-derived acidic oligosaccharides OS) } \\
\text { (15wt\%) } \\
\text { CG: Standard formula without } \\
\text { oligosaccharides. } \\
\text { BG: Breast milk }\end{array}$ & $\begin{array}{l}\text { S: before post-natal } \\
\text { age of } 8 \text { weeks } \\
\text { E: } 12 \text { months }\end{array}$ & $\begin{array}{l}\text { Formula containing a mixture of neutral } \\
\text { oligosaccharides was effective as primary } \\
\text { prevention of atopic dermatitis in low atopy risk } \\
\text { infants ( } 5.7 \% \text { in } P G \text { vs. } 9.7 \% \text { in CG, } P=0.04 \text {; } \\
7.3 \% \text { in BG) }\end{array}$ & 1 year \\
\hline $\begin{array}{l}\text { Gruber et al. } \\
\text { (85) }\end{array}$ & $\begin{array}{l}\text { double-blind, } \\
\text { controlled, } \\
\text { randomized } \\
\text { prospective } \\
\text { nutritional } \\
\text { intervention study }\end{array}$ & $\begin{array}{l}\text { Healthy term infants with } \\
\text { low atopy risk: } \\
-232 \text { infants in prebiotic formula } \\
\text { group (PG) } \\
-243 \text { infants in control formula } \\
\text { group (CG) } \\
-197 \text { infants in breast-feeding } \\
\text { group (BG) }\end{array}$ & $\begin{array}{l}\text { PG: regular formula containing aspecific } \\
\text { mixture of neutral oligosaccharides } \\
\text { [scGOS/lcFOS, ratio 9:1, }(85 \mathrm{wt} \%), \text { and } \\
\text { pectin-derived acidic oligosaccharides } \\
\text { OS)(15wt\%) } \\
\text { CG: Standard formula without } \\
\text { oligosaccharides. } \\
\text { BG: Breast milk }\end{array}$ & $\begin{array}{l}\text { S: before post-natal } \\
\text { age of } 8 \text { weeks } \\
\text { E: } 12 \text { months }\end{array}$ & $\begin{array}{l}\text { The cumulative incidence of } A D \text { up to age } 5 \\
\text { years was } 18.2 \% \text { (PG) } 20.2 \% \text { (CG) and } 23.9 \% \\
\text { (BG), therefore in this follow up study there was } \\
\text { no sustained statistically significant effect of } \\
\text { prebiotics added to infant diet against the } \\
\text { occurrence of early } A D \text { at preschool age }\end{array}$ & 5 years \\
\hline
\end{tabular}



prebiotic of human milk)

$\begin{array}{lll}\text { Pontes et al. } & \text { double-blind, } & \text { healthy children (1-4 years of age) } \\ \text { randomized, } & \text { 125: CMBB with DHA,PDX,GOS, } \\ & \text { controlled trial } & \beta \text {-glucan, and other key nutrients } \\ & & \text { 131: control }\end{array}$

Ranucci et al. randomized,

(87) double-blind,

prebiotic (GOS/PDX)-enriched

formula (PF) completed the study

104/199 infants who received an SF
until 48 weeks of life completed the

study

123/140 infants who remained on

exclusive breastfeeding until six

months of age completed the study
Prebiotic + Standard formula (or

Prebiotic

Prebiotic

Beginning of

End of treatment

(E).

\section{Outcomes}

Follow-up (duration)

Cow's Milk-Based Beverage (CMBB)

containing DHA, the prebiotics

S: $1-4$ years of age E: 28 weeks later

CMBB was associated with fewer episodes of 28 weeks.

polydextrose (PDX) and

galactooligosaccharides (GOS), $\beta$-glucan

and other nutrients including zinc, vitamin

$A$ and iron

prebiotic (mixture of $4 \mathrm{~g} / \mathrm{L}$ of $\quad S$ : birth

GOS/PDX)-enriched standard formula (PF) E: 48 weeks of life

s. identical standard formula without

\section{prebiotic}

cumulative incidence, intensity and duration of

$A D$ among groups. However, the risk of $A D$ in

PF was reduced by $35 \%$ compared with SF.

Bifidobacteria and Clostridium clusterl

colonization increased in the PF group.

Bifidobacteria was associated with Rls

protection, whereas Clostridium cluster I had a

protective role in atopy development

(B) Prebiotic +Hydrolyzed/ amino acid-based formulas.

\begin{tabular}{|c|c|c|c|c|c|c|}
\hline References & Study & Enrolled patients & $\begin{array}{l}\text { Hydrolyzed/ amino } \\
\text { acid-based formulas+ Prebiotic } \\
\text { substance }\end{array}$ & $\begin{array}{l}\text { Prebiotic } \\
\text { substance, } \\
\text { Beginning of } \\
\text { treatment (S), } \\
\text { End of treatment } \\
\text { (E). }\end{array}$ & Outcomes & Follow-up (duration) \\
\hline $\begin{array}{l}\text { Moro et al. } \\
(80)\end{array}$ & $\begin{array}{l}\text { Prospective } \\
\text { randomized, } \\
\text { double-blind } \\
\text { placebo controlled } \\
\text { trial }\end{array}$ & $\begin{array}{l}\text { 206/259 infants at high risk of atopy } \\
\text { completed the study: } \\
102 \text { infants in the prebiotic group; } \\
104 \text { infants in the placebo group }\end{array}$ & $\begin{array}{l}\text { Extensively hydrolysed cows'milk whey } \\
\text { protein formula supplemented either with } \\
8 \mathrm{~g} / \mathrm{L} \mathrm{scGOS/lcFOS} \mathrm{/} \mathrm{(prebiotic} \mathrm{group)} \mathrm{or} \\
\text { a } 8 \mathrm{~g} / \mathrm{L} \text { maltodextrin (placebo group) }\end{array}$ & $\begin{array}{l}8 \mathrm{~g} / \mathrm{L} \text { scGOS/lcFOS } \\
\text { S: within the first } 2 \\
\text { weeks of life } \\
\text { E: } 6 \text { months }\end{array}$ & $\begin{array}{l}\text { The cumulative incidence of } \mathrm{AD} \text { atopic } \\
\text { dermatitis was significantly reduced at } 6 \\
\text { months of age by prebiotics supplementation } \\
\text { ( } 9.8 \text { vs. } 23.1 \%, p<0.05 \text { ) }\end{array}$ & 6 months \\
\hline $\begin{array}{l}\text { Arslanoglu } \\
\text { et al. (88) }\end{array}$ & $\begin{array}{l}\text { Prospective } \\
\text { randomized, } \\
\text { double-blind } \\
\text { placebo controlled } \\
\text { trial }\end{array}$ & $\begin{array}{l}134 / 152 \text { infants at high risk of atopy } \\
\text { completed the study } \\
66 \text { in the prebiotic group } \\
68 \text { in the placebo group }\end{array}$ & $\begin{array}{l}\text { Extensively hydrolysed cows'milk whey } \\
\text { protein formula supplemented either with } \\
8 \mathrm{~g} / \mathrm{L} \mathrm{scGOS/lcFOS} \mathrm{/} \mathrm{(prebiotic} \mathrm{group)} \mathrm{or} \\
\text { a } 8 \mathrm{~g} / \mathrm{L} \text { maltodextrin (placebo group). }\end{array}$ & $\begin{array}{l}8 \mathrm{~g} / \mathrm{L} \text { scGOS} / \mathrm{lcFOS} \\
\text { S: within the first } 2 \\
\text { weeks of life } \\
\text { E: } 6 \text { months }\end{array}$ & $\begin{array}{l}\text { Cumulative incidences of AD, recurrent } \\
\text { wheezing, and allergic urticaria were } \\
\text { significantly reduced at } 2 \text { years of age by } \\
\text { prebiotics supplementation }(13.6 \%, 7.6 \% \text {, and } \\
1.5 \text { vs. } 27.9 \%, 20.6 \% \text { and } 10.3 \% \text { respectively, } \\
p<0.05)\end{array}$ & 2 years \\
\hline $\begin{array}{l}\text { Arslanoglu } \\
\text { et al. (89) }\end{array}$ & $\begin{array}{l}\text { Prospective } \\
\text { randomized, } \\
\text { double-blind } \\
\text { placebo controlled } \\
\text { trial, }\end{array}$ & $\begin{array}{l}92 \text { infants at high risk of atopy } \\
\text { completed the study } \\
42 \text { in the prebiotic group } \\
50 \text { in the placebo group }\end{array}$ & $\begin{array}{l}\text { Extensively hydrolysed cows'milk whey } \\
\text { protein formula supplemented either with } \\
8 \mathrm{~g} / \mathrm{L} \mathrm{scGOS/lcFOS} \mathrm{/} \mathrm{(prebiotic} \mathrm{group)} \mathrm{or} \\
\text { a } 8 \mathrm{~g} / \mathrm{L} \text { maltodextrin (placebo group). }\end{array}$ & $\begin{array}{l}8 \mathrm{~g} / \mathrm{L} \text { scGOS} / \mathrm{lcFOS} \\
\text { S: within the first } 2 \\
\text { weeks of life } \\
\text { E: } 6 \text { months }\end{array}$ & $\begin{array}{l}\text { Cumulative incidences of any allergic } \\
\text { manifestations and atopic dermatitis were } \\
\text { significantly reduced at } 5 \text { years of age by } \\
\text { prebiotics supplementation ( } 30.9 \% \text {, and } 19.1 \\
\text { vs. } 66 \text { and } 38 \% \text {, respectively, } p<0.05 \text { ) }\end{array}$ & 5 years \\
\hline
\end{tabular}


TABLE 1 | Continued

\begin{tabular}{|c|c|c|c|c|c|c|}
\hline References & Study & Enrolled patients & $\begin{array}{l}\text { Hydrolyzed/ amino } \\
\text { acid-based formulas+ Prebiotic } \\
\text { substance }\end{array}$ & $\begin{array}{l}\text { Prebiotic } \\
\text { substance, } \\
\text { Beginning of } \\
\text { treatment (S), } \\
\text { End of treatment } \\
\text { (E). }\end{array}$ & Outcomes & Follow-up (duration) \\
\hline $\begin{array}{l}\text { Francavilla } \\
\text { et al. (90) }\end{array}$ & $\begin{array}{l}\text { Prospective } \\
\text { two-phases clinical } \\
\text { trial (cross-over } \\
\text { design) }\end{array}$ & $\begin{array}{l}21 \text { infants with a confirmed CMA } \\
15 \text { healthy breast-fed infants } \\
\text { as controls }\end{array}$ & $\begin{array}{l}\text { Phase 1: extensively hydrolyzed formula } \\
\text { without lactose for } 2 \text { months } \\
\text { Phase 2: an identical extensively } \\
\text { hydrolyzed formula containing lactose } \\
(3.8 \%) \text { for an additional } 2 \text { months }\end{array}$ & 3.8\% Lactose & $\begin{array}{l}\text { The addition of lactose to an extensively } \\
\text { hydrolyzed formula increased the total fecal } \\
\text { counts of Lactobacillus/Bifidobacteria, the } \\
\text { concentration of total short-chain fatty acids, } \\
\text { mostly acetic and butyric acids and decreased } \\
\text { the counts of Bacteroides/Clostridia }\end{array}$ & 4 months \\
\hline $\begin{array}{l}\text { Boyle et al. } \\
\text { (91) }\end{array}$ & $\begin{array}{l}\text { double-blind, } \\
\text { randomized, } \\
\text { controlled } \\
\text { parallel-group } \\
\text { nutritional } \\
\text { intervention trial }\end{array}$ & $\begin{array}{l}863 \text { high-risk infants: } \\
\text { - } 432 \text { infants in the prebiotic group } \\
\text { (PG) } \\
\text { - } 431 \text { Infants fed with standard } \\
\text { foumula (CG }\end{array}$ & $\begin{array}{l}\text { PG: partially hydrolysed whey-based infant } \\
\text { formula containing a specific mixture of } \\
\text { neutral scGOS and lcFOS (9: } 1 ; 85 \text { weight } \\
\text { per cent, } 0.68 \mathrm{~g} / 100 \mathrm{ml}) \text { and acidic pAOS } \\
\text { (15 weight per cent, } 0.12 \mathrm{~g} / 100 \mathrm{ml} \text { acidic) } \\
\text { (pHF-OS) }\end{array}$ & $\begin{array}{l}\text { S: before } 18 \text { weeks } \\
\text { of life } \\
\text { E: } 6 \text { months }\end{array}$ & $\begin{array}{l}\text { pHF-OS did not prevent eczema in high-risk } \\
\text { infants in the first } 12 \text { months (Eczema occurred } \\
\text { in } 30.8 \% \text { pHF-OS vs. } 30.3 \% \text { control in all } \\
\text { infants (OR } 0.9995 \% \mathrm{Cl} 0.71,1.37 ; P=0.94 \text { ). } \\
\text { as well as by } 18 \text { months. However, pHF-OS } \\
\text { reduced cow's milk-specific lgG1 }(P<0.0001 \text { ) }\end{array}$ & 12 and 18 months \\
\hline $\begin{array}{l}\text { Wopereis } \\
\text { et al. (92) }\end{array}$ & $\begin{array}{l}\text { Double-blind, } \\
\text { randomized, } \\
\text { controlled, parallel } \\
\text { group nutritional } \\
\text { intervention trial }\end{array}$ & $\begin{array}{l}138 \text { Infants at high risk: } \\
\text { - } 51 \text { infants in the prebiotic group } \\
\text { (PG) } \\
\text { - } 57 \text { Infants fed with standard } \\
\text { foumula (CG) } \\
\text { - } 30 \text { infants in the breast-fed } \\
\text { group (BG) }\end{array}$ & $\begin{array}{l}\text { PG: Partially hydrolyzed formula containing } \\
\text { short-chain galacto-oligosaccharides and } \\
\text { long-chain fructo-oligosaccharides ( } 9: 1 \text {; } \\
0.68 \mathrm{~g} / 100 \mathrm{~mL} \text { ) and pectin-derived acidic } \\
\text { oligosaccharides ( } 0.12 \mathrm{~g} / 100 \mathrm{~mL}) \\
\text { CG: standard formula } \\
\text { BG: breast milk }\end{array}$ & $\begin{array}{l}\text { S: before } 18 \text { weeks } \\
\text { of life } \\
\text { E: } 26 \text { weeks of age }\end{array}$ & $\begin{array}{l}\text { Infants with eczema at } 18 \text { months: } 32 \% \text { in CG, } \\
39 \% \text { in PG and } 47 \% \text { in BG } \\
\text { Infants presenting eczema at } 18 \text { months } \\
\text { showed a decrease in acquisition of } \\
\text { Eubacterium and Anaerostipes species with } \\
\text { increased lactate and reduced butyrate levels }\end{array}$ & 18 months \\
\hline
\end{tabular}

Cow's milk protein allergy (CMA), Healthy controls (HC), Human milk oligosaccharides (HMO), short-chain galactooligosaccharides (scGOS), long-chain fructooligosaccharides(IcFOS), human milk oligosaccharides (HMOS), prebiotics polydextrose (PDX), galactooligosaccharides (GOS), galacto-oligosaccharide/polydextrose (GOS/PDX), Probiotic formula (PF), atopic dermatitis (AD), cow's milk-based beverage (CMBB).

Standard formula (SF), Breast feeding (BF). 
due to heterogeneity of the studies and type of prebiotics. In a longitudinal cohort study enrolling 259 high-risk infants, Moro et al. (80) found that a hydrolyzed protein cow's milk-based formula supplemented with $90 \%$ scGOS-10\% lcFOS, $(8 \mathrm{~g} / \mathrm{L})$ significantly reduced $\mathrm{AD}$ at the age of 6 months [intervention group: 9.8 vs. $23.1 \%$ placebo group $(P<0.05)]$ and increased the number of fecal bifidobacteria. Long term beneficial effect on allergy prevention (i.e., atopic dermatitis, rhinoconjunctivitis, and allergic urticaria) was also noted during the follow-up period, at 2 and 5 years of age compared to the placebo group $(88,89)$. In another RCT study (84) a $44 \%$ lower incidence of AD was reported at 1 year of life in infants at low risk of allergy fed an intact protein formula supplemented with GOS/FOS and specific pectin-derived acidic oligosaccharide compared to infants fed standard formula. It is noteworthy that the rate of $\mathrm{AD}$ in the prebiotic group was similar to that of fully breastfed babies (5.7 vs. $7.3 \%$ ) but the protective effect vanished at preschool age (85).

Supplementation with prebiotics also showed a beneficial effect when used in children aged 1-4 years old. In a doubleblind, randomized, controlled trial (86), 125 children were given cow's milk-based beverage (CMBB) containing DHA, the prebiotics polydextrose (PDX) and galactooligosaccharides (GOS), beta-glucan, zinc, iron, vitamins A and D, and were compared to 131 children fed with standard cow's milk for 28 weeks. Children who consumed CMBB had significantly reduced episodes of allergic manifestation, including eczema and urticaria, allergic rhinitis or conjunctivitis, wheezing, and allergic cough, compared to the control group. A metaanalysis (96) evaluating different types of prebiotics, duration of administration, and length of follow-up concluded for an overall $32 \%$ reduced risk of eczema and dermatitis (RR:0.68, 95\% CI: 0.48-0.97; NNT 25), but not of asthma.

However, other trials did not confirm these positive results $(83,87,91,97-100)$. In a study (83), evaluating preterm, low birth weight infants fed with a formula containing a prebiotic mixture (GOS/FOS plus acidic oligosaccharides), there was no difference in the prevalence of $\mathrm{AD}$ and bronchial hyperreactivity. In another study (91) a partially hydrolyzed formula supplemented with specific oligosaccharides (pHF-OS) induced immunomodulatory effects, such as increased regulatory T-cell numbers, in infants at increased risk of allergy, but was not able to reduce $\mathrm{AD}$ incidence at 12 or 18 months compared with standard formula-fed infants.

In 2011, the Nutrition Committee of the European Society for Pediatric Gastroenterology Hepatology and Nutrition (ESPGHAN) found insufficient evidence to recommend supplementing with prebiotics in infant formulas to prevent atopic disease (98).

In 2016, the World Allergy Organization (99), using the Grading of Recommendations Assessment, Development, and Evaluation (GRADE) approach, was in favor to use prebiotic supplementation in not-exclusively breastfed infants but reporting very low certainty of evidence. No significant difference in eczema (RR: 0.57, 95\% CI: 0.30-1.08) emerged after the meta-analysis of five studies (1,313 infants), while the meta-analysis of two studies (249 infants) found a reduction in recurrent wheeze or asthma (RR: $0.37,95 \%$ CI: $0.17-0.80$ ) in the prebiotic group of infants. Only one study assessed the risk of food allergy and found a reduced risk (RR: 0.28, 95\% CI 0.08-1.00) in infants supplemented with prebiotics.

In 2017 a systematic review performed by Cuello-Garcia et al. (100) found not enough evidence to reject or to support the use of prebiotics for allergy prevention in infants analyzing the risk of $\mathrm{AD}$ (RR: $0.68,95 \% \mathrm{CI}: 0.40-1.15)$, asthma/wheezing (RR, 0.37; 95\% CI: 0.17-0.80), and food allergy (RR: 0.28, 95\% CI: $0.08-1.00)$. No evidence of an increased risk of any adverse effects was also noted in supplemented infants (RR: 1.01, 95\% CI: 0.92-1.10). In 2018 infants with a positive family history of allergy were randomized to receive a GOS/PDX-formula (PF) or standard formula (SF) until 48 weeks of life while 140 infants were exclusively breastfed (BF): even if there was a $35 \%$ reduction in $\mathrm{AD}$ risk in PF compared with SF, there was no a statistically significant difference in any $\mathrm{AD}$ analyzed variables between the two groups at 36,48 , and 96 weeks (87).

Interestingly, in the same year, a systematic review (101) on HMOs reported a preventive effect on cow's milk allergy (CMA) at 18 months of age.

Therefore, at present, despite some promising results with specific prebiotics on the gut microbiota (102), the heterogeneity and the limited numbers of studies do not allow to draw any definitive conclusions on the clinical impact of prebiotics for allergy prevention.

As it has been suggested (103), since a large amount of prebiotics are already present in human milk, more carefully conducted RCTs in formula-fed infants, at high as well at low risk of allergy, are still needed before routine prebiotic supplementation can be recommended for allergy prevention.

\section{PROBIOTICS TO PREVENT ALLERGIC DISEASES}

Recent evidence suggests that exposure to beneficial bacteria in early life may have a role in the prevention of allergy (72). A number of studies first demonstrated that infants born vaginally and breastfed are colonized by Lactobacilli and Bifidobacteria whilst infants born through cesarean section and fed with standard formula show a significantly lower prevalence of Bifidobacteria and more Bacteroides and Coliforms (72) associated with increased prevalence of respiratory allergies (104). Thus, probiotic supplementation during pregnancy was considered to transfer beneficial bacteria to the infant during delivery and after birth. Secondly, the gut is highly exposed to microbial exposure and immune stimulation (105) and probiotic supplementation early in life may facilitate the maturation of the immune system $(106,107)$. Based on these hypotheses, most trials evaluating probiotics for prevention of allergy are based on supplementation during pregnancy, lactation; and/or post-natally. The route of administration varied from oral preparation (capsules; oil droplets; and suspension), addition to infant formula, maternal intake in breastfed babies, or a combination of the above (108). Various microbial species have been tested, in primis Lactobacillus and Bifidobacterium, alone 
or in combination with other species, such as Propionibacterium, Streptococcus, Lactococcus, and Escherichia coli (Table 2).

At present, the strains of probiotics tested for prevention of allergy are considered as generally safe during pregnancy and in infancy (81) although adverse effects have not been fully assessed in all studies. We hereby summarize studies and metaanalysis evaluating the efficacy of probiotics on prevention of atopic dermatitis (the most relevant reported outcome) and other allergic manifestations (rhinitis, rhinoconjunctivitis, asthma and/or wheezing, food allergy, and/or their combination).

\section{Evidence on Prevention of Atopic Dermatitis (AD)}

The pioneering study using Lactobacillus GG probiotic supplementation in pregnant women, breastfeeding mothers, and infants at high risk of allergy, demonstrated a reduced prevalence of early $\mathrm{AD}$ in children compared to the control group (109). Noteworthy, specific Toll-like receptor genetic variations were associated with the protection of eczema by two probiotic strains (Lactobacillus rhamnosus HN001 and Bifidobacterium lactis HN019), suggesting that individual genetic factors might influence the efficacy and outcome of probiotic supplementation (110).

Table 2 shows details of published RCTs on this topic, with several studies supporting $(109,111-126)$, while others providing no evidence (127-139), for recommending probiotics in primary prevention of atopic disease.

Conflicting results and conclusions also emerged from reviews, meta-analyses, and guidelines in the last 12 years. Two Cochrane reviews dated 2007 and 2011 did not provide guidance and showed many uncertainties $(140,141)$. Osborn's first metaanalysis (140) recognized an effect on the prevention of atopic dermatitis, but heterogeneity across studies hampered the draw of definitive conclusions. Afterward, the meta-analysis by Lee et al. (142) analyzed data from a total of 1,581 patients for perinatal administration and showed a preventive effect with a RR of 0.69 (CI: 0.57-0.83). Betsi and colleagues (143) analyzed three studies (584 patients) reporting a significantly decreased incidence of dermatitis in two of them. In 2012 Doege et al. (144), analyzed seven RCTs that reported a modest preventive effect on AD (RR: 0.82, CI: $0.71-0.95 ; 2,843$ patients) with Lactobacilli, but not with mixtures of probiotics $(128,129)$. In the same year, a larger meta-analysis of 13 studies documented a significant preventive effect (RR: 0.79, CI: 0.71-0.88) (145). No difference was found between specific strains nor for target populations (pregnant mothers, breastfeeding mothers, or infants). One year later, a systematic review of 9 studies reported a reduced risk of $\mathrm{AD}$ with estimated efficacy ranging from 30 to $70 \%$ (146).

In 2015 the WAO (10) reviewed 23 RCTs: in 7 trials the supplementation of probiotics was only in infants $(117,118$, $131,147-150)$, in 8 trials was in pregnant women and infants $[(136,149,151-154)$, while in the other 8 was in pregnant women, breastfeeding mothers and infants $(109,112,112,114$, $116,130,136)]$. Fifteen randomized trials of probiotics given to infants measured development of eczema $(106,109,114,116-$ $118,129,130,134,136,148-150,155,156)$. When used during pregnancy, probiotics were usually supplemented in the last 3 months (10) resulting in a decreased risk of eczema in children, compared to placebo (RR: 0.72, 95\%, CI: 0.61-0.85). According to these results, the WAO guideline concluded that (tested) probiotics assumed by pregnant women provide a clear benefit, primarily for the prevention of eczema, in high-risk infants; however, it was a "conditional recommendation," based on "very low-quality evidence" (10). The same conclusion (conditional recommendation, very low-quality evidence) was drawn in favor of probiotics considering the reduced rate of eczema when compared to placebo (RR $0.61,95 \%$ CI from 0.50 to 0.64 ) in breastfeeding mothers (10) and in infants (RR 0.81, 95\% CI 0.70 0.94).

Two other meta-analyses published in 2015 documented a clear benefit of probiotics only for primary prevention of eczema but did not report significant preventive effects of any other allergic manifestations $(108,151)$. Zuccotti et al. (151) analyzed 17 studies (4,755 children) and found that probiotics supplementation was associated with a significantly lower relative risk (RR) for developing eczema compared with placebo ( $R R$ 0.78; 95\% CI: 0.69-0.89), and the most pronounced effect was obtained in particular when heterogeneous mixtures of probiotic strains were used (RR 0.54; 95\% CI: 0.43-0.68) (but no with Lactobacilli or Bifidobacteria alone).

The metanalysis by Cuello-Garcia et al. (108) evaluating 29 studies reported a reduced risk of eczema (follow-up period until 2 years of age) when probiotics were given in the last 3 months of pregnancy ( $\mathrm{RR} 0.71 ; 95 \% \mathrm{CI}, 0.60-0.84$ ), in breastfeeding mothers (RR 0.57 ; 95\% CI, 0.47-0.69), or both to infants and mothers (RR, 0.80; 95\% CI, 0.68-0.94), but not when administered only to infants (RR, 0.83 ; 95\% CI, 0.58-1.19). However, using the GRADE approach, there was a low or very low certainty of evidence due to the "risk of bias, inconsistency and imprecision of results, and indirectness of available research" (108). Results supporting a stronger efficacy of combined perinatal supplementation were reported by two subsequent reviews $(34,153)$. In particular, according to the Italian review (34), there was "a moderate but constant effect across studies available in the literature for the prevention of atopic dermatitis among children at risk of allergy with the administration of probiotics to the mother during pregnancy and/or after delivery, and to their child during the first 6 months of life." Similarly, in the most recent review and meta-analysis by Li et al. (153), assessing 28 studies, probiotic supplementation was reported as protective against atopic eczema (OR: 0.69, 95\% CI: 0.58 $0.82, P<0.0001)$ and only pre-natal combined with postnatal supplementation obtained a significant reduction. However, it was still open to question when during the gestation the supplementation should start and for how long the intervention should continue in the post-natal period $(103,152)$.

Moreover, many other clinical studies and meta-analyses reported conflicting results $(109,140,144,145,150,154-$ 159). These discrepancies could be likely related to different study designs, populations, probiotic strains, and dosages used. As a single strain, LGG showed the most beneficial effect (157) in particular on reducing total and specific immunoglobulin E (IgE) sensitization (158). Conversely, 
TABLE 2 | Probiotics administration in prevention of allergic disorders.

(A) Probiotic given orally (eg droplets, suspensions, capsules) or with breastfeeding/ standard formula.

\begin{tabular}{|c|c|c|c|c|c|c|c|c|}
\hline References & Study & $\begin{array}{l}\text { Enrolled } \\
\text { patients }\end{array}$ & $\begin{array}{l}\text { Probiotic }+ \\
\text { Standard formula/breast } \\
\text { Feeding }\end{array}$ & $\begin{array}{l}\text { Probiotic strain, } \\
\text { Beginning of treatment } \\
\text { (S), } \\
\text { End of treatment (E). }\end{array}$ & $\begin{array}{l}\text { Pre- } \\
\text { natal administra- } \\
\text { tion } \\
\text { (duration) }\end{array}$ & $\begin{array}{l}\text { Post-natal } \\
\text { administration } \\
\text { (duration) }\end{array}$ & Outcomes & $\begin{array}{l}\text { Follow-up } \\
\text { (duration) }\end{array}$ \\
\hline $\begin{array}{l}\text { Kalliomaki et al. } \\
\text { (109) }\end{array}$ & $\begin{array}{l}\text { double-blind, } \\
\text { randomized, } \\
\text { placebo- } \\
\text { controlled } \\
\text { trial }\end{array}$ & $\begin{array}{l}\text { - } 159 \text { Pregnant } \\
\text { woman who } \\
\text { had at least } \\
\text { one } \\
\text { first-degree } \\
\text { relative (or } \\
\text { partner) with } \\
\text { atopic } \\
\text { disease } \\
\text { - breastfeeding } \\
\text { mothers } \\
\text { - their infants, } \\
\text { post-natally if } \\
\text { not } \\
\text { breast-fed }\end{array}$ & $\begin{array}{l}\text { Placebo group ( } n=82) \text { : two } \\
\text { capsules of placebo } \\
\text { (microcrystalline cellulose) } \\
\text { Probiotic group ( } n=77) \text { : two } \\
\text { capsules of } 1 \times 10^{10} \mathrm{CFU} \text { of } \\
\text { Lactobacillus } \mathrm{GG} \text { daily: for } \\
\text { infants contents were mixed } \\
\text { with water and given by spoon }\end{array}$ & $\begin{array}{l}\text { Pregnant woman: } \\
\text { S: } 2-4 \text { weeks before } \\
\text { expected delivery } \\
\text { E: at delivery or } 6 \text { months } \\
\text { later if breastfeeding } \\
\text { mothers } \\
\text { Infants: } \\
\text { S: birth } \\
\text { E: } 6 \text { months }\end{array}$ & $\begin{array}{l}2-4 \text { weeks before } \\
\text { expected delivery }\end{array}$ & 6 months & $\begin{array}{l}\text { There was a halving in frequency of atopic } \\
\text { eczema in the probiotic group compared } \\
\text { with the placebo group ( } 15 / 64 \text { [23\%] vs. } \\
31 / 68 \text { [46\%]; relative risk } 0.51 \text { [95\% Cl } \\
0.32-0.84]) \text {. The number needed to treat } \\
\text { was } 4.5 \text { (95\% } \mathrm{Cl} 2.6-15.6)\end{array}$ & 2 years \\
\hline Rautava et al. (111) & $\begin{array}{l}\text { parallel, } \\
\text { double-blind } \\
\text { placebo- } \\
\text { controlled } \\
\text { trial }\end{array}$ & $\begin{array}{l}205 \text { pregnant } \\
\text { women with } \\
\text { allergic disease } \\
\text { and atopic } \\
\text { sensitization }\end{array}$ & $\begin{array}{l}\text { Probiotic groups: } \\
\text { - } 1 \text { sachet of L.rhamnosus LPR } \\
(1 \times 109 \text { CFU) and B. longum } \\
\text { BL999 }(1 \times 109 \text { CFU }(N= \\
73) \text { daily or } \\
\text { - L paracasei ST11 }(1 \times 109 \\
\text { CFU) and B longum BL999 }(1 \\
\times 109 \text { CFU) daily }(N=70) \\
\text { Placebo group }(n=62) \text { : the } \\
\text { same sachet } \\
\text { without probiotics }\end{array}$ & $\begin{array}{l}\text { S: } 2 \text { months before expeted } \\
\text { delivery } \\
\text { E: } 2 \text { months after delivery } \\
\text { (during breast-feeding) }\end{array}$ & $\begin{array}{l}2 \text { months before } \\
\text { expeted delivery to } \\
\text { delivery }\end{array}$ & 2 months & $\begin{array}{l}\text { There was a significantly reduced risk of } \\
\text { developing eczema in infants of mothers } \\
\text { receiving LPR1BL999 (odds ratio [OR], } \\
0.17 ; 95 \% \mathrm{Cl} \text {, 0.08-0.35; } P<.001 \text { ) and } \\
\text { ST111BL999 (OR, 0.16; 95\% Cl, } \\
\text { 0.08-0.35; } P<.001 \text { ) }\end{array}$ & 2 years \\
\hline $\begin{array}{l}\text { Kalliomäki et al. } \\
(112)\end{array}$ & $\begin{array}{l}\text { double-blind, } \\
\text { randomi-zed, } \\
\text { placebo- } \\
\text { controlled } \\
\text { trial }\end{array}$ & $\begin{array}{l}\text { - } 132 \text { Pregnant } \\
\text { woman who } \\
\text { had at least } \\
\text { one } \\
\text { first-degree } \\
\text { relative (or } \\
\text { partner) with } \\
\text { atopic } \\
\text { disease } \\
\text { - breastfeeding } \\
\text { mothers } \\
\text { - their infants, } \\
\text { post-natally if } \\
\text { not } \\
\text { breast-fed }\end{array}$ & $\begin{array}{l}\text { Placebo group ( } n=53) \text { : two } \\
\text { capsules of placebo } \\
\text { (microcrystalline cellulose) } \\
\text { Probiotic group ( } n=54) \text { : two } \\
\text { capsules of } 1 \times 10^{10} \mathrm{CFU} \text { of } \\
\text { Lactobacillus } \mathrm{GG} \text { daily: for } \\
\text { infants contents were mixed } \\
\text { with water and given by spoon }\end{array}$ & $\begin{array}{l}\text { Pregnant woman: } \\
\text { S: } 2-4 \text { weeks before } \\
\text { expected delivery } \\
\text { E: at delivery or } 6 \text { months } \\
\text { later if breastfeeding } \\
\text { mothers } \\
\text { Infants: } \\
\text { S: birth } \\
\text { E: } 6 \text { months }\end{array}$ & $\begin{array}{l}2-4 \text { weeks before } \\
\text { expected delivery }\end{array}$ & 6 months & $\begin{array}{l}\text { There was an extention beyond infancy of } \\
\text { the preventive effect of lactobacillus GG on } \\
\text { atopic eczema: (14/53 in probiotic group } \\
\text { developped eczema vs. } 25 / 54 \text { receiving } \\
\text { placebo (relative risk } 0.57,95 \% \mathrm{Cl} \\
0.33-0.97 \text { ) }\end{array}$ & 4 years \\
\hline
\end{tabular}


TABLE 2 | Continued

\begin{tabular}{|c|c|c|c|c|c|c|c|c|}
\hline References & Study & $\begin{array}{l}\text { Enrolled } \\
\text { patients }\end{array}$ & $\begin{array}{l}\text { Probiotic }+ \\
\text { Standard formula/breast } \\
\text { Feeding }\end{array}$ & $\begin{array}{l}\text { Probiotic strain, } \\
\text { Beginning of treatment } \\
\text { (S), } \\
\text { End of treatment (E). }\end{array}$ & $\begin{array}{l}\text { Pre- } \\
\text { natal administra- } \\
\text { tion } \\
\text { (duration) }\end{array}$ & $\begin{array}{l}\text { Post-natal } \\
\text { administration } \\
\text { (duration) }\end{array}$ & Outcomes & $\begin{array}{l}\text { Follow-up } \\
\text { (duration) }\end{array}$ \\
\hline $\begin{array}{l}\text { Kalliomäki et al. } \\
\text { (113) }\end{array}$ & $\begin{array}{l}\text { double-blind, } \\
\text { randomized, } \\
\text { placebo- } \\
\text { controlled } \\
\text { trial }\end{array}$ & $\begin{array}{l}\text { - } 116 \text { Pregnant } \\
\text { woman who } \\
\text { had at least } \\
\text { one } \\
\text { first-degree } \\
\text { relative (or } \\
\text { partner) with } \\
\text { atopic } \\
\text { disease } \\
\text { - breastfeeding } \\
\text { mothers } \\
\text { - their infants, } \\
\text { post-natally if } \\
\text { not } \\
\text { breast-fed }\end{array}$ & $\begin{array}{l}\text { Placebo group ( } n=62) \text { : two } \\
\text { capsules of placebo } \\
\text { (microcrystalline cellulose) } \\
\text { Probiotic group ( } n=53 \text { ): two } \\
\text { capsules of } 1 \times 10^{10} \mathrm{CFU} \text { of } \\
\text { Lactobacillus GG daily: for } \\
\text { infants contents were mixed } \\
\text { with water and given by spoon }\end{array}$ & $\begin{array}{l}\text { Pregnant woman: } \\
\text { S: } 2-4 \text { weeks before } \\
\text { expected delivery } \\
\text { E: at delivery or } 6 \text { months } \\
\text { later if breastfeeding } \\
\text { mothers Infants: } \\
\text { S: birth } \\
\text { E: } 6 \text { months }\end{array}$ & $\begin{array}{l}2-4 \text { weeks before } \\
\text { expected delivery }\end{array}$ & 6 months & $\begin{array}{l}\text { The cumulative risk for developing eczema } \\
\text { was significantly lower in the L.GG group } \\
\text { than in the placebo group ( } 42.6 \% \text { vs. } \\
66.1 \% \text {; RR, } 0.64 ; 95 \% \mathrm{Cl}, 0.45-0.92) \\
\text { According to Cox regression, the risk of } \\
\text { eczema was significantly reduced in the L. } \\
\text { GG group (odds ratio, } 0.58 ; 95 \% \mathrm{Cl} \text {, } \\
0.35-0.94 ; P=0.027 \text { ) }\end{array}$ & 7 years \\
\hline Wickens et al. (114) & $\begin{array}{l}\text { Double-blind, } \\
\text { randomized } \\
\text { placebo- } \\
\text { controlled } \\
\text { trial }\end{array}$ & $\begin{array}{l}\text { - Pregnant } \\
\text { women who } \\
\text { had at least } \\
\text { one } \\
\text { first-degree } \\
\text { relative (or } \\
\text { partner) with } \\
\text { atopic } \\
\text { disease, } \\
\text { - breast } \\
\text { feeding } \\
\text { mothers } \\
\text { - their infants }\end{array}$ & $\begin{array}{l}\text { Two Probiotic groups(capsule } \\
\text { powder with): } \\
\text { - Lactobacillus rhamnosus } \\
\text { HN001 ( } N=170) \\
\text { - Bifidobacterium animalis } \\
\text { subsp lactis strain HNO19 ( } N \\
=171) \\
\text { Placebo group: }(N=171) \text { : } \\
\text { capsule powder } \\
\text { without probiotics }\end{array}$ & $\begin{array}{l}\text { Pregnant women: } \\
\text { Lactobacillus rhamnosus } \\
\text { HN001 ( } 63109 \text { CFU /d), } \\
\text { Bifidobacterium animalis } \\
\text { subsp lactis strain HNO19 }(9 \\
\times 3109 \text { CFU /d) or placebo } \\
\text { daily from } 35 \text { weeks } \\
\text { gestation until } 6 \text { months if } \\
\text { breast-feeding } \\
\text { Infants: same treatment } \\
\text { from day 2-16 of life to } \\
2 \text { years }\end{array}$ & $\begin{array}{l}\text { From } 35 \text { weeks } \\
\text { gestation }\end{array}$ & $\begin{array}{l}\text { Breast feeding } \\
\text { mothers: for } 6 \\
\text { months } \\
\text { Infants: for } 2 \\
\text { years since } \\
\text { day } 2-16 \text { of life }\end{array}$ & $\begin{array}{l}\text { infants receiving } L \text { rhamnosus had a } \\
\text { significantly }(P=0.01) \text { reduced risk of } \\
\text { eczema (hazard ratio [HR], } 0.51 ; 95 \% \mathrm{Cl} \text {, } \\
0.30-0.85 \text { ) compared with placebo, but } \\
\text { this was not the case for B animalis subsp } \\
\text { lactis ( } \mathrm{HR}, 0.90 ; 95 \% \mathrm{Cl}, 0.58-1.41 \text { ) }\end{array}$ & 2 years \\
\hline Dotterud et al. (115) & $\begin{array}{l}\text { randomized, } \\
\text { double-blind } \\
\text { trial }\end{array}$ & $\begin{array}{l}415 \text { pregnant } \\
\text { women }\end{array}$ & $\begin{array}{l}\text { Probiotic group }(n=138) \text { : } \\
\text { probiotic milk contained LGG } 5 \\
\times 1010 \text { CFU, Bb-12 } 5 \times 1010 \\
\text { CFU and La- } 5.5 \times 109 \text { CFU } \\
\text { daily. } \\
\text { Placebo group }(N=140) \text { : the } \\
\text { placebo milk contained no } \\
\text { probiotic bacteria }\end{array}$ & $\begin{array}{l}\text { S: } 4 \text { weeks before expected } \\
\text { delivery date } \\
\text { E: } 3 \text { months after delivery } \\
\text { (while breastfeeding) }\end{array}$ & $\begin{array}{l}4 \text { weeks (from } 36 \\
\text { weeks of gestation) }\end{array}$ & $\begin{array}{l}3 \text { months while } \\
\text { brestfeeding }\end{array}$ & $\begin{array}{l}\text { There was a odds ratio }(\mathrm{OR}) \text { of } 0.51 \text { for the } \\
\text { cumulative incidence of } \mathrm{AD} \text { in the probiotic } \\
\text { group compared with the placebo }[95 \% \mathrm{Cl} \text {, } \\
0.30-0.87 ; P=0.013] \text {. There were no } \\
\text { significant effects on asthma or atopic } \\
\text { sensitiza- tion }\end{array}$ & 2 years \\
\hline Kim et al. (116) & $\begin{array}{l}\text { randomized, } \\
\text { double-blind, } \\
\text { placebo- } \\
\text { controlled } \\
\text { trial }\end{array}$ & $\begin{array}{l}112 \text { pregnant } \\
\text { women and } \\
\text { newborns }\end{array}$ & $\begin{array}{l}\text { Probiotics group: mixture of } \mathrm{B} \text {. } \\
\text { bifidum BGN4 }\left[1.6 \times 10^{9} \mathrm{CFU}\right] \\
\mathrm{B} \text {. lactis } \mathrm{AD} 011\left(1.6 \times 10^{9}\right. \\
\mathrm{CFU}) \text {, and } \mathrm{L} \text {. acidophilus } \mathrm{AD0} 31 \\
\left(1.6 \times 10^{9} \mathrm{CFU}\right) \text { in } 0.72 \mathrm{~g} \text { of } \\
\text { maltodextrin and } 0.8 \mathrm{~g} \text { of } \\
\text { alpha-corn once daily } \\
\text { Placebo group: maltodextrin } \\
\text { and alpha-corn without } \\
\text { probiotic bacteria }\end{array}$ & $\begin{array}{l}\mathrm{S} \text { (women): } \\
4-8 \text { weeks before expected } \\
\text { delivery } \\
\mathrm{E} \text { (women): } 3 \text { months after } \\
\text { delivery (during } \\
\text { breastfeeding) } \\
\mathrm{S} \text { (infants): } 4 \text { months after } \\
\text { delivery } \\
\text { E(infants): } 6 \text { months }\end{array}$ & $\begin{array}{l}4-8 \text { weeks before } \\
\text { expected delivery to } \\
\text { delivery }\end{array}$ & 6 months & $\begin{array}{l}\text { There was a significant reduction in the } \\
\text { cumulative incidence of eczema during the } \\
\text { first year in probiotic group ( } 36.4 \% \text { vs. } \\
62.9 \%, p=0.029)\end{array}$ & 1 year \\
\hline
\end{tabular}


TABLE 2 | Continued

\begin{tabular}{|c|c|c|c|c|c|c|c|c|}
\hline References & Study & $\begin{array}{l}\text { Enrolled } \\
\text { patients }\end{array}$ & $\begin{array}{l}\text { Probiotic }+ \\
\text { Standard formula/breast } \\
\text { Feeding }\end{array}$ & $\begin{array}{l}\text { Probiotic strain, } \\
\text { Beginning of treatment } \\
\text { (S), } \\
\text { End of treatment }(E) .\end{array}$ & $\begin{array}{l}\text { Pre- } \\
\text { natal administra- } \\
\text { tion } \\
\text { (duration) }\end{array}$ & $\begin{array}{l}\text { Post-natal } \\
\text { administration } \\
\text { (duration) }\end{array}$ & Outcomes & $\begin{array}{l}\text { Follow-up } \\
\text { (duration) }\end{array}$ \\
\hline West et al. (117) & $\begin{array}{l}\text { double-blind, } \\
\text { placebo- } \\
\text { controlled } \\
\text { randomized } \\
\text { intervention trial }\end{array}$ & $\begin{array}{l}179 \text { infants } \\
\text { during weaning }\end{array}$ & $\begin{array}{l}\text { Probiotic group }(n=89) \text { : fed } \\
\text { cereals with Lactobacillus F19 } \\
\text { Placebo group }(N=90) \text { : fed } \\
\text { cereals without probiotics }\end{array}$ & $\begin{array}{l}\text { S: } 4 \text { months } \\
\text { E: } 13 \text { months }\end{array}$ & no & 9 months & $\begin{array}{l}\text { There was a cumulative incidence of } \\
\text { eczema of } 11 \%(4-17 \%, 95 \% \mathrm{Cl}) \text { in the } \\
\text { probiotic group vs. } 22 \%(13-31 \%, 95 \% \mathrm{Cl}) \\
\text { in the placebo group }(p<0.05)\end{array}$ & 13 months \\
\hline $\begin{array}{l}\text { Lodinova-Zadnikova } \\
\text { et al. (118) }\end{array}$ & $\begin{array}{l}\text { controlled } \\
\text { clinical trial }\end{array}$ & $\begin{array}{l}158 \text { infants: } \\
-N=56 \\
\text { colonized } \\
\text { infants of } \\
\text { allergic } \\
\text { mothers, } \\
N=57 \\
\text { control infants } \\
\text { of allergic } \\
\text { mothers } \\
\text { - } N=45 \\
\text { control infants } \\
\text { of } \\
\text { healthy mothers }\end{array}$ & $\begin{array}{l}\text { One milliliter of E. coli was } \\
\text { administered to infants of } \\
\text { allergic mothers }\end{array}$ & $\begin{array}{l}\text { S: within } 48 \mathrm{~h} \text { after birth and } \\
\text { subsequently } 3 \text { times a } \\
\text { week } \\
\text { E: } 4 \text { weeks }\end{array}$ & no & 4 weeks & $\begin{array}{l}\text { There were allergy symptoms in } 14 \text { infants } \\
\text { of control allergic mothers, in } 7 \text { infants of } \\
\text { healthy mothers, and in } 2 \text { colonized infants } \\
\text { of allergic mothers }\end{array}$ & 5 years \\
\hline Ezaki et al. (119) & $\begin{array}{l}\text { Retrospective } \\
\text { study }\end{array}$ & $\begin{array}{l}30 \text { newborns } \\
\text { after small } \\
\text { intestine } \\
\text { surgery }\end{array}$ & $\begin{array}{l}\text { Probiotic group ( } N=18 \\
\text { newborns GA } 34.5(23.5-38.4) \text { : } \\
\text { suspension of } B . \text { breve } \\
\left(7.5 \times 10^{8} \text { cells/day). }\right. \\
\text { Placebo group }(N=12 \\
\text { newborn, GA } 34.4 \text { (26.4-40.0): }\end{array}$ & $\begin{array}{l}\text { S: After small intestine } \\
\text { sugery } \\
\text { E: when full enteral } \\
\text { feeding ( } 100 \mathrm{ml} / \mathrm{kg} / \text { day }) \\
\text { was reached }\end{array}$ & no & $\begin{array}{l}\text { After } \\
\text { small intestine } \\
\text { surgery until } \\
\text { full enteral } \\
\text { feeding (100 } \\
\mathrm{ml} / \mathrm{kg} / \text { day) } \\
\text { was reached }\end{array}$ & $\begin{array}{l}\text { Administration of probiotics reduced the } \\
\text { incidence of cow's milk protein intolerance } \\
\text { (CMPI) after small intestine surgery (one vs. } \\
\text { eight, } p<0.001 \text { ) }\end{array}$ & \\
\hline Wickens et al. (120) & $\begin{array}{l}\text { Double-blind, } \\
\text { randomized } \\
\text { placebo- } \\
\text { controlled } \\
\text { trial }\end{array}$ & $\begin{array}{l}\text { - Pregnant } \\
\text { women who } \\
\text { had at least } \\
\text { one } \\
\text { first-degree } \\
\text { relative (or } \\
\text { partner) with } \\
\text { atopic } \\
\text { disease, } \\
\text { - breast } \\
\text { feeding } \\
\text { mothers } \\
\text { - their infants } \\
\text { (N=425) }\end{array}$ & $\begin{array}{l}\text { Two Probiotic groups: } \\
\text { - Lactobacillus rhamnosus } \\
\text { HN001 } \\
\text { - Bifidobacterium animalis } \\
\text { subsp lactis strain HN019 } \\
\text { Placebo group: }\end{array}$ & $\begin{array}{l}\text { Pregnant women: } \\
\text { Lactobacillus rhamnosus } \\
\text { HNO01 }(6 \times 3109 \text { CFU/d), } \\
\text { Bifidobacterium animalis } \\
\text { subsp lactis strain HNO19 }(9 \\
\times 3109 \mathrm{CFU} / \mathrm{d}) \text { or placebo } \\
\text { daily from } 35 \text { weeks } \\
\text { gestation until } 6 \text { months if } \\
\text { breast-feeding } \\
\text { Infants: same treatment } \\
\text { from day 2-16 of life to } \\
2 \text { years }\end{array}$ & $\begin{array}{l}\text { From } 35 \text { weeks } \\
\text { gestation }\end{array}$ & $\begin{array}{l}\text { Breast feeding } \\
\text { mothers: for } 6 \\
\text { months } \\
\text { Infants: for } 2 \\
\text { years since } \\
\text { day 2-16 of life }\end{array}$ & $\begin{array}{l}\text { The cumulative prevalence of eczema } \\
\text { [Hazard ratio (HR) } 0.57 \text { ( } 95 \% \mathrm{Cl} 0.39-0.83)] \\
\text { and prevalence of rhinoconjunctivitis } \\
\text { [Relative risk } 0.38 \text { ( } 95 \% \mathrm{Cl} 0.18-0.83)] \\
\text { were significantly reduced in the children } \\
\text { taking HN } 001 ; \mathrm{HN} 019 \text { did not affect the } \\
\text { prevalence of any outcome }\end{array}$ & 4 years \\
\hline
\end{tabular}


TABLE 2 | Continued

\begin{tabular}{|c|c|c|c|c|c|c|c|c|}
\hline References & Study & $\begin{array}{l}\text { Enrolled } \\
\text { patients }\end{array}$ & $\begin{array}{l}\text { Probiotic }+ \\
\text { Standard formula/breast } \\
\text { Feeding }\end{array}$ & $\begin{array}{l}\text { Probiotic strain, } \\
\text { Beginning of treatment } \\
\text { (S), } \\
\text { End of treatment (E). }\end{array}$ & $\begin{array}{l}\text { Pre- } \\
\text { natal administra- } \\
\text { tion } \\
\text { (duration) }\end{array}$ & $\begin{array}{l}\text { Post-natal } \\
\text { administration } \\
\text { (duration) }\end{array}$ & Outcomes & $\begin{array}{l}\text { Follow-up } \\
\text { (duration) }\end{array}$ \\
\hline Wickens et al. (121) & $\begin{array}{l}\text { Double-blind, } \\
\text { randomized } \\
\text { placebo- } \\
\text { controlled } \\
\text { trial }\end{array}$ & $\begin{array}{l}\text { - Pregnant } \\
\text { women who } \\
\text { had at least } \\
\text { one } \\
\text { first-degree } \\
\text { relative (or } \\
\text { partner) with } \\
\text { atopic } \\
\text { disease, } \\
\text { - breast } \\
\text { feeding } \\
\text { mothers } \\
\text { - their infants } \\
(N=425)\end{array}$ & $\begin{array}{l}\text { Two Probiotic groups: } \\
\text { - Lactobacillus rhamnosus } \\
\text { HNO01 } \\
\text { - Bifidobacterium animalis } \\
\text { subsp lactis strain HN019 } \\
\text { Placebo group: }\end{array}$ & $\begin{array}{l}\text { Pregnant women: } \\
\text { Lactobacillus rhamnosus } \\
\text { HNO01 }(6 \times 3109 \mathrm{CFU} / \mathrm{d}) \text {, } \\
\text { Bifidobacterium animalis } \\
\text { subsp lactis strain HNO19 }(9 \\
\times 3109 \mathrm{CFU} / \mathrm{d}) \text { or placebo } \\
\text { daily from } 35 \text { weeks } \\
\text { gestation until } 6 \text { months if } \\
\text { breast-feeding } \\
\text { Infants: same treatment } \\
\text { from day } 2-16 \text { of life to } \\
2 \text { years }\end{array}$ & $\begin{array}{l}\text { From } 35 \text { weeks } \\
\text { gestation }\end{array}$ & $\begin{array}{l}\text { Breast feeding } \\
\text { mothers: for } 6 \\
\text { months } \\
\text { Infants: for } 2 \\
\text { years since } \\
\text { day } 2-16 \text { of life }\end{array}$ & $\begin{array}{l}\text { HNO01 was associated with significantly } \\
\text { lower cumulative prevalence of eczema (HR } \\
=0.56,95 \% \mathrm{Cl} 0.39-0.80) \text {, SCORAD } \geq 10 \\
\text { (HR }=0.69,0.49-0.98) \text { and SPT } \\
\text { sensitization ( } \mathrm{HR}=0.69,95 \% \mathrm{Cl} \\
0.48-0.99) \text {. HNO19 had no significant effect } \\
\text { on any outcome }\end{array}$ & 6 years \\
\hline Wickens et al. (122) & $\begin{array}{l}\text { Double-blind, } \\
\text { randomized } \\
\text { placebo- } \\
\text { controlled } \\
\text { trial }\end{array}$ & $\begin{array}{l}\text { - Pregnant } \\
\text { women who } \\
\text { had at least } \\
\text { one } \\
\text { first-degree } \\
\text { relative (or } \\
\text { partner) with } \\
\text { atopic } \\
\text { disease, } \\
\text { - breast } \\
\text { feeding } \\
\text { mothers } \\
\text { - their infants }\end{array}$ & $\begin{array}{l}\text { Two Probiotic groups: } \\
\text { - Lactobacillus rhamnosus } \\
\text { HN001 ( } N=97 \text { ) } \\
\text { - Bifidobacterium animalis } \\
\text { subsp lactis strain HN019 ( } N \\
=104) \\
\text { Placebo group: }(N=97) \\
\text { The capsule powder was } \\
\text { either given undiluted to the } \\
\text { infant or mixed with water, } \\
\text { breast milk, or formula and } \\
\text { given via a teaspoon or } \\
\text { syringe or sprinkled on food. }\end{array}$ & $\begin{array}{l}\text { Pregnant women: } \\
\text { Lactobacillus rhamnosus } \\
\text { HNO01 }(6 \times 3109 \\
\text { colony-forming units/d), } \\
\text { Bifidobacterium animalis } \\
\text { subsp lactis strain HNO19 }(9 \\
\times 3109 \text { colony-forming } \\
\text { units/d) or placebo daily } \\
\text { from } 35 \text { weeks gestation } \\
\text { until } 6 \text { months if } \\
\text { breast-feeding } \\
\text { Infants: same treatment } \\
\text { from day 2-16 of life to } \\
2 \text { years }\end{array}$ & $\begin{array}{l}\text { From } 35 \text { weeks } \\
\text { gestation }\end{array}$ & $\begin{array}{l}\text { Breast feeding } \\
\text { mothers: for } 6 \\
\text { months } \\
\text { Infants: for } 2 \\
\text { years since } \\
\text { day } 2-16 \text { of life }\end{array}$ & $\begin{array}{l}\text { HNO01 significantly reduced the 12-month } \\
\text { prevalence of eczema at age } 11 \text { years } \\
\text { (relative risk }[\mathrm{RR}]=0.46,95 \% \mathrm{Cl} \\
0.25-0.86, P=0.015) \text { and hay fever (RR }= \\
0.73,95 \% \mathrm{Cl} 0.53-1.00, P=0.047) \text {. } \\
\text { HNO01 was associated with a significant } \\
\text { reduction in lifetime prevalence of atopic } \\
\text { sensitization (hazard ratio }[\mathrm{HR}]=0.71,95 \% \\
\mathrm{Cl} 0.51-1.00, P=0.048) \text {, eczema (HR }= \\
0.58,95 \% \mathrm{Cl} 0.41-0.82, P=0.002) \text { and } \\
\text { wheeze }(\mathrm{HR}=0.76,95 \% \mathrm{Cl} 0.57-0.99, P \\
=0.046) . \mathrm{HNO} 19 \text { had no significant effect }\end{array}$ & 11 years \\
\hline Bertelsen et al. (123) & $\begin{array}{l}\text { large, } \\
\text { prospecti-ve } \\
\text { pregnancy } \\
\text { cohort study }\end{array}$ & $\begin{array}{l}\text { 40,614 mothers } \\
\text { and children }\end{array}$ & $\begin{array}{l}\text { probiotic milk products } \\
\text { containing } L \text {. acido-philus } L A-5 \text {, } \\
\text { B. lactis } B b 12,+/-L \text {. } \\
\text { rhamno-sus GG }\end{array}$ & $\begin{array}{l}\text { S(mother): during } \\
\text { pregnancy } \\
\text { S(infants): } \\
\text { after } 6 \text { months } \\
\text { E: } 18 \text { months }\end{array}$ & during pregnancy & $\begin{array}{l}\text { Mothers: } \\
\text { during } \\
\text { breast-feeding } \\
\text { Infants: from } 6 \\
\text { to } 18 \text { months } \\
\text { of age }\end{array}$ & $\begin{array}{l}\text { Consumption of probiotic milk in pregnancy } \\
\text { was associated with a slightly reduced risk } \\
\text { [(adjusted RR (aRR)] of atopic eczema at } 6 \\
\text { months aRR }=0.94 \text { ( } 95 \% \mathrm{Cl}: 0.89,0.99) \\
\text { and of rhinoconjuctivitis between } 18 \text { and } 36 \\
\text { months, aRR }=0.87 \text { ( } 95 \% \mathrm{Cl}: 0.78,0.98) \text {; } \\
\text { the adjusted relative risk of } \\
\text { rhinoconjunctivitis was aRR }=0.80 \text { ( } 95 \% \mathrm{Cl} \text { : } \\
0.68,0.93 \text { ) when both mother and infant } \\
\text { had consumed probiotic milk }\end{array}$ & 36 months \\
\hline
\end{tabular}


TABLE 2 | Continued

\begin{tabular}{|c|c|c|c|c|c|c|c|c|}
\hline References & Study & $\begin{array}{l}\text { Enrolled } \\
\text { patients }\end{array}$ & $\begin{array}{l}\text { Probiotic }+ \\
\text { Standard formula/breast } \\
\text { Feeding }\end{array}$ & $\begin{array}{l}\text { Probiotic strain, } \\
\text { Beginning of treatment } \\
\text { (S), } \\
\text { End of treatment (E). }\end{array}$ & $\begin{array}{l}\text { Pre- } \\
\text { natal administra- } \\
\text { tion } \\
\text { (duration) }\end{array}$ & $\begin{array}{l}\text { Post-natal } \\
\text { administration } \\
\text { (duration) }\end{array}$ & Outcomes & $\begin{array}{l}\text { Follow-up } \\
\text { (duration) }\end{array}$ \\
\hline Simpson et al. (124) & $\begin{array}{l}\text { Double-blinded, } \\
\text { randomized } \\
\text { placebo- } \\
\text { controlled } \\
\text { trial }\end{array}$ & $\begin{array}{l}161 \text { pregnant } \\
\text { women }\end{array}$ & $\begin{array}{l}\text { Probiotic group }(N=81) \text { : } \\
\text { probiotic milk contained LGG } 5 \\
\times 1010 \mathrm{CFU}, \mathrm{Bb}-125 \times 1010 \\
\mathrm{CFU} \text { and La- } 5.5 \times 109 \mathrm{CFU} \\
\text { daily. } \\
\text { Placebo group }(N=80) \text { : the } \\
\text { placebo milk contained no } \\
\text { probiotic bacteria }\end{array}$ & $\begin{array}{l}\text { S: } 4 \text { weeks before expected } \\
\text { delivery date } \\
\text { E: } 3 \text { months after delivery } \\
\text { (while breastfeeding) }\end{array}$ & $\begin{array}{l}4 \text { weeks (from } 36 \\
\text { weeks of gestation) }\end{array}$ & $\begin{array}{l}3 \text { months while } \\
\text { brestfeeding }\end{array}$ & $\begin{array}{l}\text { There was a trend toward a lower } \\
\text { cumulative incidence of } \mathrm{AD} \text { in the probiotic } \\
\text { group (OR } 0.64,95 \% \mathrm{Cl} 0.39-1.07, p= \\
0.086 \text {; NNT }=10 \text { ). This finding was } \\
\text { statistically significantly in the complete } \\
\text { case analysis (OR } 0.48,95 \% \mathrm{Cl} \\
0.25-0.92, p=0.027, \mathrm{NNT}=6 \text { ) }\end{array}$ & 6 years \\
\hline Schmidt et al. (126) & $\begin{array}{l}\text { double-blind, } \\
\text { placebo- } \\
\text { controlled } \\
\text { intervention trial }\end{array}$ & $\begin{array}{l}290 \text { infants } \\
\text { aged } 8 \text { to } 14 \\
\text { months (Mean } \\
\text { age } 10.1 \\
\text { months) }\end{array}$ & $\begin{array}{l}\text { Probiotic group }(N=144) \text { : } \mathrm{B} \text {. } \\
\text { animalis subsp lactis and } \mathrm{L} \text {. } \\
\text { rhamnosus ( } 10^{9} \mathrm{CFU} \text { of each) } \\
\text { daily + maltodextrin powder } \\
\text { Placebo group ( } N=146) \text { : } \\
\text { maltodextrin powder }\end{array}$ & $\begin{array}{l}\text { S: up to } 12 \text { weeks before } \\
\text { expected } \\
\text { start in child care. } \\
\text { E: after } 6 \text { months }\end{array}$ & no & 6 months & $\begin{array}{l}\text { A significantly lower incidence of eczema } \\
\text { was observed in the probiotic group } \\
\text { compared to the placebo group ( } 4.2 \% \text { vs. } \\
11.5 \%, P=0.036 \text { ). The incidence of } \\
\text { asthma, rhinitis, conjunctivitis, and } \\
\text { sensitization did not differ }\end{array}$ & 6 months \\
\hline Peldan et al. (127) & $\begin{array}{l}\text { double-blinded, } \\
\text { placebo- } \\
\text { control-led } \\
\text { study }\end{array}$ & $\begin{array}{l}1223 \text { mothers } \\
\text { with infants at } \\
\text { high risk for } \\
\text { allergy }\end{array}$ & $\begin{array}{l}445 \text { mothers received } \\
\text { probiotic's mixture: LGG }(5 \times \\
\left.10^{9} \mathrm{cfu}\right), \mathrm{L} \text { rhamnosus } \mathrm{LC} 705 \text { ( } 5 \\
\left.\times 10^{9} \mathrm{cfu}\right) \text {, B. breve Bb99 }(2 \times \\
\left.10^{8} \mathrm{cfu}\right) \text {, and Propionibacterium } \\
\text { freudenreichii ssp. shermanii JS } \\
\left(2 \times 10^{9} \mathrm{cfu} \text { ) twice daily. }\right. \\
\text { Their infants received the same } \\
\text { probiotic capsule + syrup } \\
\text { containing } 0.8 \mathrm{~g} \text { of } \\
\text { galacto-oligosaccharides once } \\
\text { daily } \\
446 \text { mothers and infants } \\
\text { received capsules containing } \\
\text { microcrystalline cellulose, } \\
\text { (placebo) and the infants also } \\
\text { received syrup without galacto- } \\
\text { oligosaccharides }\end{array}$ & $\begin{array}{l}\text { S (women): From } 36 \text { weeks } \\
\text { of gestation, } \\
\text { E (women): at delivery } \\
S \text { (infants): birth } \\
\text { E (infants): } 6 \text { months }\end{array}$ & $\begin{array}{l}\text { From } 36 \text { weeks of } \\
\text { gestation, }\end{array}$ & $\begin{array}{l}\text { from birth until } \\
\text { age } 6 \text { months. }\end{array}$ & $\begin{array}{l}\text { the prevalence of allergic } \\
\text { rhino-conjunctivitis was greater in the } \\
\text { probiotic group compared to the placebo } \\
\text { group ( } 36.5 \% \text { vs. } 29.0 \% \text {, OR: } 1.43,95 \% \\
\text { Cl: } 1.06-1.94, p=0.03\end{array}$ & $5-10$ years \\
\hline Taylor et al. (128) & $\begin{array}{l}\text { Randomized, } \\
\text { double-blind, } \\
\text { placebo- } \\
\text { controlled } \\
\text { trial }\end{array}$ & $\begin{array}{l}178 \text { newborns } \\
\text { at high risk of } \\
\text { allergy: } \\
\text { - Probiotic } \\
\text { group }(n= \\
\text { 89) } \\
\text { - Placebo } \\
\text { group }(n=89)\end{array}$ & $\begin{array}{l}\text { Probiotic group: } 3 \times 10^{9} \mathrm{~L} \text {. } \\
\text { acidophilus LAVRI-A1 once a } \\
\text { day(in sachet packets) } \\
\text { Placebo group: Maltodrexine }\end{array}$ & $\begin{array}{l}\text { S: births } \\
\text { E: } 6 \text { months }\end{array}$ & no & 6 months & $\begin{array}{l}\text { Early probiotic supplementation with } \mathrm{L} \\
\text { acidophilus did not reduce the risk of } \mathrm{AD} \text { at } \\
12 \text { months of age ( } 38 / 88 \text { vs. } 34 / 87 \text { in } \\
\text { the placebo) and was associated with } \\
\text { increased allergen sensitization ( } 35 / 88 \\
\text { vs. } 21 / 86 \text { ) }\end{array}$ & 12 months \\
\hline
\end{tabular}


TABLE 2 | Continued

\begin{tabular}{|c|c|c|c|c|c|c|c|c|}
\hline References & Study & $\begin{array}{l}\text { Enrolled } \\
\text { patients }\end{array}$ & $\begin{array}{l}\text { Probiotic }+ \\
\text { Standard formula/breast } \\
\text { Feeding }\end{array}$ & $\begin{array}{l}\text { Probiotic strain, } \\
\text { Beginning of treatment } \\
\text { (S), } \\
\text { End of treatment (E). }\end{array}$ & $\begin{array}{l}\text { Pre- } \\
\text { natal administra- } \\
\text { tion } \\
\text { (duration) }\end{array}$ & $\begin{array}{l}\text { Post-natal } \\
\text { administration } \\
\text { (duration) }\end{array}$ & Outcomes & $\begin{array}{l}\text { Follow-up } \\
\text { (duration) }\end{array}$ \\
\hline $\begin{array}{l}\text { Abrahamsson et al. } \\
\text { (129) }\end{array}$ & $\begin{array}{l}\text { prospective } \\
\text { double-blind, } \\
\text { placebo- } \\
\text { controlled, } \\
\text { multicenter trial }\end{array}$ & $\begin{array}{l}188 \text { mothers } \\
\text { with allergic } \\
\text { disease } \\
\text { Their infants } \\
\text { continued with } \\
\text { the } \\
\text { same product }\end{array}$ & $\begin{array}{l}\text { Probiotic group: oil }+L \text { reuteri } \\
\text { ATCC } 55730\left(1 \times 10^{8} \mathrm{CFU}\right) \\
\text { daily } \\
\text { Placebo group: (CFUs): the } \\
\text { same oil without probiotics }\end{array}$ & $\begin{array}{l}S \text { (Women): } 36 \text { weeks of } \\
\text { gestational age } \\
E \text { (women): delivery } \\
S \text { (infants): at birth } \\
E \text { (infants): } 12 \text { months }\end{array}$ & $\begin{array}{l}\text { from gestational } \\
\text { week } 36 \text { until } \\
\text { delivery. }\end{array}$ & 12 months & $\begin{array}{l}\text { The cumulative incidence of eczema was } \\
\text { similar, } 36 \% \text { in the treated vs. } 34 \% \text { in the } \\
\text { placebo group. The probiotic group had } \\
\text { less lgE-associated eczema during the } \\
\text { second year, } 8 \% \text { vs. } 20 \% \text { ( } P=0.02) \text {, }\end{array}$ & 2 years \\
\hline Kopp et al. (130) & $\begin{array}{l}\text { Randomized, } \\
\text { Double-Blind, } \\
\text { Placebo- } \\
\text { Controlled } \\
\text { Trial }\end{array}$ & $\begin{array}{l}\text { - } 94 \text { pregnant } \\
\text { women with a } \\
\text { family history } \\
\text { of atopic } \\
\text { disease } \\
\text { - } 89 \\
\text { breastfeeding } \\
\text { mothers } \\
\text { - their infants ( } \\
=94 \text { : } \\
5 \text { not } \\
\text { breastfeed } \\
\text { infants from } \\
\text { birth, } 89 \text { from } \\
\text { the age of } \\
3 \text { months) }\end{array}$ & $\begin{array}{l}\text { L-GG group: } 1 \text { capsule }\left(5 \times 10^{9}\right. \\
\text { CFU) of L- GG twice } \\
\text { Daily } \\
(N=50) \\
\text { Placebo group: capsules of } \\
\text { microcrystalline cellulose }(N \\
=44)\end{array}$ & $\begin{array}{l}S \text { (women): } 4 \text { to } 6 \text { weeks } \\
\text { before expected delivery, } \\
\text { then during } \\
\text { breastfeeding for } 3 \text { months; } \\
S \text { (infants): } \\
5 \text { infants from birth, } 89 \text { from } \\
\text { the age of } 3 \text { months } \\
E \text { (women): at delivery or } \\
\text { after } 3 \text { months if } \\
\text { breastfeeding } \\
E \text { (infants): } 6 \text { months of age }\end{array}$ & 4-6 weeks & 6 months & $\begin{array}{l}\text { Supplementation with } L-G G \text { neither } \\
\text { reduced the incidence of } A D \text { ( } 28 \% \text { vs. } \\
27.3 \%, P=0.93 \text { ) nor altered the severity of } \\
\text { AD but was associated with an increased } \\
\text { rate of recurrent wheezing bronchitis ( } 26 \% \\
\text { vs. } 9.1 \% P=0.03 \text { ) }\end{array}$ & 2 years \\
\hline Prescott et al. (131) & $\begin{array}{l}\text { Randomized, } \\
\text { double-blind, } \\
\text { placebo- } \\
\text { controlled } \\
\text { trial }\end{array}$ & $\begin{array}{l}153 \text { newborns } \\
\text { at high risk of } \\
\text { allergy: } \\
\text { - Probiotic } \\
\text { group ( } N= \\
74 \text { ) } \\
\text { - Placebo } \\
\text { group ( } N \\
=76)\end{array}$ & $\begin{array}{l}\text { Probiotic group: } 3 \times 10^{9} \mathrm{~L} \text {. } \\
\text { acidophilus LAVRI-A1 once a } \\
\text { day(in sachet packets) } \\
\text { Placebo group: Maltodrexine }\end{array}$ & $\begin{array}{l}\text { S: births } \\
\text { E: } 6 \text { months }\end{array}$ & no & 6 months & $\begin{array}{l}\text { Supplementation with this probiotic did not } \\
\text { reduce the risk of dermatitis }(31 / 74,42 \%) \\
\text { compared with placebo group }(25 / 76 \text {, } \\
34 \%) \text {. There was no significant reduction in } \\
\text { any other allergic disease or allergen } \\
\text { sensitization }\end{array}$ & 2.5 years \\
\hline
\end{tabular}


TABLE 2 | Continued

\begin{tabular}{|c|c|c|c|c|c|c|c|c|}
\hline References & Study & $\begin{array}{l}\text { Enrolled } \\
\text { patients }\end{array}$ & $\begin{array}{l}\text { Probiotic }+ \\
\text { Standard formula/breast } \\
\text { Feeding }\end{array}$ & $\begin{array}{l}\text { Probiotic strain, } \\
\text { Beginning of treatment } \\
\text { (S), } \\
\text { End of treatment (E). }\end{array}$ & $\begin{array}{l}\text { Pre- } \\
\text { natal administra- } \\
\text { tion } \\
\text { (duration) }\end{array}$ & $\begin{array}{l}\text { Post-natal } \\
\text { administration } \\
\text { (duration) }\end{array}$ & Outcomes & $\begin{array}{l}\text { Follow-up } \\
\text { (duration) }\end{array}$ \\
\hline Kuitunen et al. (133) & $\begin{array}{l}\text { double-blinded, } \\
\text { placebo- } \\
\text { control-led } \\
\text { study }\end{array}$ & $\begin{array}{l}1223 \text { mothers } \\
\text { with infants at } \\
\text { high risk for } \\
\text { allergy }\end{array}$ & $\begin{array}{l}445 \text { mothers received probiotic } \\
\text { 's mixture: LGG }\left(5 \times 10^{9} \mathrm{cfu}\right), \mathrm{L} \\
\text { rhamnosus LC705 }\left(5 \times 10^{9}\right. \\
\text { cfu), B. breve Bb99 }\left(2 \times 10^{8} \mathrm{cfu}\right) \text {, } \\
\text { and Propionibacterium } \\
\text { freudenreichii ssp. shermanii JS } \\
\left(2 \times 10^{9} \mathrm{cfu}\right) \text { twice daily. } \\
\text { Their infants received the same } \\
\text { probiotic capsule + syrup } \\
\text { containing } 0.8 \mathrm{~g} \text { of } \\
\text { galacto-oligosaccharides once } \\
\text { daily } \\
446 \text { mothers and infants } \\
\text { received capsules containing } \\
\text { microcrystalline cellulose, } \\
\text { (placebo) and the infants also } \\
\text { received syrup without galacto- } \\
\text { oligosaccharides }\end{array}$ & $\begin{array}{l}\text { S (women): From } 36 \text { weeks } \\
\text { of gestation, } \\
\text { E (women): at delivery } \\
\text { S (infants): birth } \\
\text { E (infants): } 6 \text { months }\end{array}$ & $\begin{array}{l}\text { From } 36 \text { weeks of } \\
\text { gestation, }\end{array}$ & $\begin{array}{l}\text { from birth until } \\
\text { age } 6 \text { months }\end{array}$ & $\begin{array}{l}\text { No significant difference appeared in } \\
\text { frequencies of eczema (39.3\% vs. } 43.3 \% \text { ), } \\
\text { atopic eczema ( } 24.0 \% \text { vs. } 25.1 \%) \text {, allergic } \\
\text { rhinitis ( } 20.7 \% \text { vs. } 19.1 \%) \text {, or asthma } \\
\text { ( } 13.0 \% \text { vs. } 14.1 \% \text { ) between groups. } \\
\text { However, less lgE-associated allergic } \\
\text { disease occurred in cesarean- delivered } \\
\text { children receiving probiotics ( } 24.3 \% \text { vs. } \\
40.5 \% \text {; odds ratio, } 0.47 ; 95 \% \mathrm{Cl}, 0.23 \% \text { to } \\
0.96 \% ; P 5.035 \text { ) }\end{array}$ & 5 years \\
\hline Niers et al. (134) & $\begin{array}{l}\text { Double-blind, } \\
\text { randomized, } \\
\text { placebo- } \\
\text { controlled } \\
\text { trial }\end{array}$ & $\begin{array}{l}98 \text { pregnant } \\
\text { women with a } \\
\text { family history of } \\
\text { allergic } \\
\text { diseases and } \\
\text { their infants }\end{array}$ & $\begin{array}{l}\text { Probiotic group }(N=50) \text { : } \\
\text { sachets containing B. bifidum ( } 1 \\
\times 109 \text { CFU), B. lactis }(1 \times 109 \\
\text { CFU), and L. lactis }(1 \times 109 \\
\text { CFU) daily } \\
\text { Placebo group }(N=48) \text { : rice } \\
\text { starch and maltodextran }\end{array}$ & $\begin{array}{l}\text { S: last } 6 \text { weeks of } \\
\text { pregnancy } \\
\text { E: } 12 \text { months after delivery } \\
\text { (to infants) }\end{array}$ & $\begin{array}{l}\text { last } 6 \text { weeks of } \\
\text { pregnancy }\end{array}$ & 12 months & $\begin{array}{l}\text { Cumulative incidence of eczema at } 1 \text { and } 2 \\
\text { years was } 23 / 50 \text { (intervention) vs. } 31 / 48 \\
\text { (placebo) and } 27 \text { (intervention) vs. } 34 \\
\text { (placebo), respectively }\end{array}$ & 2 years \\
\hline Boyle et al. (135) & $\begin{array}{l}\text { Randomized } \\
\text { controlled trial }\end{array}$ & $\begin{array}{l}250 \text { pregnant } \\
\text { women carrying } \\
\text { infants at high } \\
\text { risk of allergic } \\
\text { disease }\end{array}$ & $\begin{array}{l}\text { Probiotic group: Lactobacillus } \\
\text { rhamnosus GG (LGG) } 1.8 \times \\
10^{10} \mathrm{CFU} / \text { day } \\
\text { Placebo group }\end{array}$ & $\begin{array}{l}\text { S: } 36 \text { weeks of gestation } \\
\text { E: at delivery }\end{array}$ & $\begin{array}{l}\text { From } 36 \text { weeks of } \\
\text { gestation until } \\
\text { delivery }\end{array}$ & no & $\begin{array}{l}\text { Pre-natal probiotic treatment was not } \\
\text { associated with reduced risk of eczema } \\
\text { (34\% probiotic, 39\% placebo; RR 0.88; } \\
95 \% \mathrm{Cl} 0.63,1.22 \text { ) or lgE-associated } \\
\text { eczema }(18 \% \text { probiotic, } 19 \% \text { placebo; RR } \\
0.94 ; 95 \% \mathrm{Cl} 0.53,1.68)\end{array}$ & \\
\hline Ou et al. (136) & $\begin{array}{l}\text { randomized, } \\
\text { double-blind, } \\
\text { placebo- } \\
\text { controlled } \\
\text { trial }\end{array}$ & $\begin{array}{l}191 \text { pregnant } \\
\text { women with } \\
\text { atopic } \\
\text { diseases, } \\
\text { breastfeeding } \\
\text { mothers or non- } \\
\text { breastfeeding } \\
\text { neonates, }\end{array}$ & $\begin{array}{l}\text { Probiotic group }(N=95): L G G \\
\text { ATCC 53103, } 1 \times 1010 \mathrm{CFU} \\
\text { daily } \\
\text { Control group }(N=96)\end{array}$ & $\begin{array}{l}\text { S (women): from the second } \\
\text { trimester of pregnancy; } \\
\text { E: } 6 \text { months after delivery } \\
\text { (breastfeeding mothers or } \\
\text { non-breast-feeding infants } \\
\text { from birth) }\end{array}$ & $\begin{array}{l}\text { From the } 24 \text { weeks } \\
\text { of gestational age to } \\
\text { delivery }\end{array}$ & 6 months & $\begin{array}{l}\text { There was no significant difference } \\
\text { between the cumulative risk of sensitization } \\
\text { and developing allergic disease at the age } \\
\text { of first } 36 \text { months by log-rank test ( } P= \\
0.86 \text { and } P=0.74 \text {, respectively) }\end{array}$ & 3 years \\
\hline
\end{tabular}


TABLE 2 | Continued

\begin{tabular}{|c|c|c|c|c|c|c|c|c|}
\hline References & Study & $\begin{array}{l}\text { Enrolled } \\
\text { patients }\end{array}$ & $\begin{array}{l}\text { Probiotic }+ \\
\text { Standard formula/breast } \\
\text { Feeding }\end{array}$ & $\begin{array}{l}\text { Probiotic strain, } \\
\text { Beginning of treatment } \\
\text { (S), } \\
\text { End of treatment (E). }\end{array}$ & $\begin{array}{l}\text { Pre- } \\
\text { natal administra- } \\
\text { tion } \\
\text { (duration) }\end{array}$ & $\begin{array}{l}\text { Post-natal } \\
\text { administration } \\
\text { (duration) }\end{array}$ & Outcomes & $\begin{array}{l}\text { Follow-up } \\
\text { (duration) }\end{array}$ \\
\hline Damm et al. (137) & $\begin{array}{l}\text { Controlled } \\
\text { interventional } \\
\text { cohort } \\
\text { study }\end{array}$ & $\begin{array}{l}527 \text { preterm } \\
\text { neonates }(<30 \\
\text { weeks of } \\
\text { gestation) }\end{array}$ & $\begin{array}{l}\text { Probiotic group }(N=249) \text { : L. } \\
\text { rhamnosus } G G\left(1 \times 10^{9}\right) \text { and } \\
\text { B. animalis subsp. lactis }(\mathrm{BB} 12) \\
\left(1 \times 10^{8}\right) \text { daily } \\
\text { Control group }(N=278) \text { : not } \\
\text { treated with probiotics }\end{array}$ & $\begin{array}{l}\text { S: third day of life } \\
\text { E: at discharge } \\
\text { from hospital, }\end{array}$ & no & $\begin{array}{l}\text { from the third } \\
\text { day of life to } \\
\text { discharge from } \\
\text { hospital }\end{array}$ & $\begin{array}{l}\text { The prevalence of AD was similar in the two } \\
\text { groups }(20.9 \% \text { in the probiotic treated } \\
\text { group vs. } 17.1 \% \text { in the not treated group, } p \\
=0.33 \text { ) }\end{array}$ & 2-8 years \\
\hline Laursen et al. (138) & $\begin{array}{l}\text { randomized, } \\
\text { double-blind, } \\
\text { placebo- } \\
\text { controlled } \\
\text { study }\end{array}$ & $\begin{array}{l}290 \text { infants } \\
\text { aged } 8 \text { to } 14 \\
\text { months }\end{array}$ & $\begin{array}{l}\text { Probiotic group }(N=144 \\
\text { B. animalis subsp lactis and } \mathrm{L} \text {. } \\
\text { rhamnosus }\left(10^{9} \mathrm{CFU}\right. \\
\text { of each) daily + maltodextrin } \\
\text { powde } \\
\text { Placebo group }(N=146) \text { : } \\
\text { maltodextrin powder }\end{array}$ & $\begin{array}{l}\text { S: up to } 12 \text { weeks before } \\
\text { expected start in child care. } \\
\text { E: after } 6 \text { months }\end{array}$ & & 6 months & $\begin{array}{l}\text { Probiotic treatment did not reduce the } \\
\text { number of days absent from child care due } \\
\text { to infections in healthy infants at the time of } \\
\text { enrollment in child care }\end{array}$ & 6 months \\
\hline Murphy et al. (139) & $\begin{array}{l}\text { Sub-Sample } \\
\text { Analysis From a } \\
\text { randomized, } \\
\text { controlled, } \\
\text { 3-arm trial } \\
(115,116)\end{array}$ & $\begin{array}{l}\text { - Pregnant } \\
\text { women who } \\
\text { had at least } \\
\text { one } \\
\text { first-degree } \\
\text { relative (or } \\
\text { partner) with } \\
\text { atopic } \\
\text { disease, } \\
\text { - breast } \\
\text { feeding } \\
\text { mothers } \\
\text { - their infants }\end{array}$ & $\begin{array}{l}\text { Two Probiotic groups: } \\
\text { - Lactobacillus rhamnosus } \\
\text { HN001 }(N=285 \text { stools) } \\
\text { - Bifidobacterium animalis } \\
\text { subsp lactis strain HN019 ( } N \\
=50 \text { stools) } \\
\text { Placebo group: ( } N=315 \\
\text { stools sample) }\end{array}$ & $\begin{array}{l}\text { Pregnant women: } \\
\text { Lactobacillus rhamnosus } \\
\text { HNO01 }(6 \times 3109 \\
\text { colony-forming units/d), } \\
\text { Bifidobacterium animalis } \\
\text { subsp lactis strain HNO19 (9 } \\
\times 3109 \text { colony-forming } \\
\text { units/d) or placebo daily } \\
\text { from } 35 \text { weeks gestation } \\
\text { until } 6 \text { months if } \\
\text { breast-feeding } \\
\text { Infants: same treatment } \\
\text { from day 2-16 of life to } \\
2 \text { years }\end{array}$ & $\begin{array}{l}\text { From } 35 \text { weeks } \\
\text { gestation }\end{array}$ & $\begin{array}{l}\text { Breast feeding } \\
\text { mothers: for } 6 \\
\text { months } \\
\text { Infants: for } 2 \\
\text { years since } \\
\text { day 2-16 of life }\end{array}$ & $\begin{array}{l}\text { Supplementation with L. rhamnosus } \\
\text { HNO01 was associated with increased } \\
\text { overall glycerol-3 phosphate transport } \\
\text { capacity and enrichment of L. rhamnosus. } \\
\text { There were no differences in development } \\
\text { of eczema by } 2 \text { years in either community } \\
\text { alpha or beta diversity }(P>0.05)\end{array}$ & 2 years \\
\hline
\end{tabular}

(B) Probiotic given with hydrolyzed/ amino acid-based formulas.

\begin{tabular}{|c|c|c|c|c|c|c|c|c|}
\hline References & Study & $\begin{array}{l}\text { Enrolled } \\
\text { Patients }\end{array}$ & $\begin{array}{l}\text { Hydrolyzed/ amino } \\
\text { acid-based } \\
\text { formulas+probiotic }\end{array}$ & $\begin{array}{l}\text { Probiotic Strain, } \\
\text { Beginning of Treatment } \\
\text { (S), } \\
\text { End of Treatment (E). }\end{array}$ & $\begin{array}{l}\text { Pre-natal } \\
\text { administration (if } \\
\text { yes: duration) }\end{array}$ & $\begin{array}{l}\text { Post-natal } \\
\text { amministration } \\
\text { (if yes: } \\
\text { duration) }\end{array}$ & Outcomes & $\begin{array}{l}\text { Follow-Up } \\
\text { (duration) }\end{array}$ \\
\hline $\begin{array}{l}\text { Berni Canani et al. } \\
\text { (125) }\end{array}$ & $\begin{array}{l}\text { Parallel-arm } \\
\text { randomized } \\
\text { controlled trial }\end{array}$ & $\begin{array}{l}220 \text { children } \\
\text { with cow's milk } \\
\text { allergy with a } \\
\text { median age of } \\
5.0 \text { months }\end{array}$ & $\begin{array}{l}\text { Probiotic group ( } N=110) \text { : } \\
\text { Extensively hydrolyzed } \\
\text { casein formula (EHCF) + } \\
\text { Lactobacillus } \\
\text { rhamnosus } G G(L G G) \\
\text { Control group }(N=110) \text { : } \\
\text { Extensively hydrolyzed } \\
\text { casein formula (EHCF) }\end{array}$ & $\begin{array}{l}\text { Lactobacillus } \\
\text { rhamnosus GG (LGG) } \\
\text { S: after randomization } \\
\text { E: } 3 \text { years }\end{array}$ & no & 36 months & $\begin{array}{l}\text { EHCF+LGG reduces the incidence of } \\
\text { allergic manifestations (AM)(absolute risk } \\
\text { difference was } 20.23(95 \% \mathrm{Cl}, 20.36 \text { to } \\
20.10 ; P<.001) \text {, and speeds up the time to } \\
\text { development of oral tolerance in children } \\
\text { with IgE-mediated CMA }\end{array}$ & 36 months \\
\hline
\end{tabular}


Lactobacillus acidophilus has been associated with an increased risk of atopic sensitization (158).

\section{Evidence on Prevention of Allergic Rhinitis (AR)}

Development of allergic rhinitis (AR) in the child following supplementation of probiotics in pregnant women has been evaluated in 5 studies $(112,114,115,129,133)$ reviewed by Fiocchi et al. (10]. No significant effect has been reported (RR $0.86,95 \%$ CI $0.44-1.7)$.

Three trials evaluated the onset of AR after supplementing with probiotics breastfeeding mothers and infants (112, 114, 115). Again, relatively few events have been observed and the results were inconclusive (RR 0.86, 95\% CI 0.21-3.47). Four trials assessed the development of AR following infant supplementation $(120,128,138,142)$ and confirmed the lack of efficacy of probiotics (RR $0.83,95 \%$ CI from 0.39 to 1.79 ).

However, in a large cohort study (123), the mothers of 40,614 children were asked to consume two brands of milk and yogurt that contain probiotic strains (L. acido-philus LA-5, B. lactis Bb12, +/- L. rhamnosus GG) during pregnancy. A slight reduction of the risk [adjusted $\mathrm{RR}(\mathrm{aRR})=0.87)$ ] of rhinoconjunctivitis at 18-36 months was reported (123). The association between rhinoconjunctivitis and probiotics appeared increased in the case of both the mother (during pregnancy) and the child (from 6 months of age) had consumed these probiotics, as compared when only mother or child consumed.

Conversely, in a longitudinal trial, a higher prevalence of allergic rhino-conjunctivitis at the age of 5-10 years was noted in the probiotic group as compared with the placebo group (36.5 vs. $29.0 \%, p=0.03)(127)$.

Therefore, at present, there is no clear evidence that probiotics prevent AR (160), with some reports demonstrating even a detrimental effect (99).

\section{Evidence on Prevention of Asthma and/or Wheezing}

Several systematic reviews and meta-analyses $(10,161,162)$ failed to demonstrate a protective effect of probiotics supplementation during pregnancy or early life in the subsequent development of asthma or wheezing. Surprisingly, even an increase in respiratory infections has been reported in children supplemented with probiotics (161).

In $2014 \mathrm{a}$ systematic review and meta-analysis (162) evaluating pre-and post-natal supplementation with probiotics concluded that there was insufficient data to recommend probiotics for the prevention of asthma and wheezing.

In 2015, the WAO analysis (10) of 8 studies (113-115, $129,133,135,136,163)$ focusing on the development of asthma/wheezing in the child following administration of probiotics to pregnant women, did not show differences between probiotic and placebo arms (RR 0.93, 95\% CI of 0.76-1.1 5). No differences were recorded between probiotic and placebo arms (RR of $1.05,95 \%$ CI from 0.59 to 1.87 ) in the 4 studies that evaluated asthma/wheezing $(113-115,136)$ after supplementation of mothers both during pregnancy and during the breastfeeding period and/or supplementation of the infant, Similarly, no differences between the probiotic and placebo groups ( $R R$ 0.98, 95\% CI from 0.78 to 1.23 ) were found in the development of asthma/wheezing in the nine studies that evaluate the effect of infants supplementation $(10,113,114,117$, $118,129,131,133,136,163)$.

\section{Evidence on Prevention of Food Allergy}

A variety of studies provided data that probiotics, including LGG or L. acidophilus, do not protect against CMA in infancy $(128,148,164)$. Moreover, in a review involving 1,549 infants, Osborn and Sinn (140) stated that the benefit of probiotics in reducing food hypersensitivity is disputable.

In a study conducted by Morisset et al. (150), children at high-risk for the onset of atopic disease were fed with standard infant formula or a fermented infant formula containing heatkilled Bifidobacterium breve C50 and Streptococcus thermophilus 065. No statistical differences in the incidence of CMA were observed between these two groups, despite infants fed the formula containing probiotics were less sensitized to CMP at skin prick tests (150).

Similarly, a reduced skin prick test sensitivity to CMP or hen's egg protein at age 6 months was reported (165) in children, following supplementation with Lactobacillus and Bifidobacterium daily to pregnant women (from 36 weeks gestation to delivery) and to infants (from birth through 6 months), when compared to mothers and infants receiving placebo.

However, the results of these studies suggested that probiotics may modulate the development of allergic sensitization to foods, but not necessarily this translates into food allergy prevention (166). Food hypersensitivity is not always associated with symptoms of food allergy, although infants with food sensitization may be more prone to develop a food allergy.

Newborns who received small intestine surgery and antibiotics showed a higher incidence (67\%) of CMPI compared to the group supplemented with probiotic treatment ( $B$. breve) (119).

Two other studies reported conflicting results with supplementation of LGG $(167,168)$ (RR 0.88 (95\%CI: 0.76-1.03).

Guidelines published in 2014 by the European Academy of Allergy and Clinical Immunology's Taskforce on the prevention of food allergy suggested that there was not enough evidence to support the routine use of probiotics for food allergy prevention (169).

In 2015, the WAO systematic review and meta-analysis (10) reviewed studies evaluating probiotics given to pregnant women $(111,112,129)$, breastfeeding mothers $(111,112)$, and infants $(112,118,129,131,150)$, and did not document significant effects in reducing the risk of developing food allergy in infants.

Conversely, another meta-analysis (170) in 2016 indicated that probiotics administered pre-natally and post-natally were effective in reducing the risk of atopy and food hypersensitivity (RR 0.77, 95\% CI: 0.61-0.98), particularly in families at high risk for allergy. Based on subgroup analyses, the preventive effect was higher when probiotics were administered to both mother and infant, or for a longer duration of the intervention 
(170), whilst no effect of post-natal probiotic supplementation alone (direct to child) was observed. Only 1 study (135) used solely pre-natal supplementation, and no significant difference in effect was observed between groups. Interestingly, one trial (133) showed that probiotic and prebiotic supplementation during pregnancy and infancy conferred protection preferably to cesarean-delivered children who could not be exposed to remarkable microbial load from a vaginal delivery.

A few studies showed conflicting results of probiotics (LGG) supplementing an extensively hydrolyzed formula in the acquisition of tolerance in infants with CMA $(171,172)$. Reducing the duration of CMA would be relevant to decrease the possible related risk of other clinical conditions including functional gastrointestinal disorders (173).

To our knowledge, studies exploring the effects of probiotics on confirmed food allergy are surprisingly scant and did not show evidence of benefit compared to non-intervention (111, 128, 165, 170, 174).

\section{Evidence on Prevention of Whatever Combination of Allergic Diseases Other Than AD}

Supplementation with probiotics did not protect against food allergy, asthma, or allergic rhinitis according to two metanalyses published in $2013(158,161)$ and the WAO review (10) that evaluated four randomized trials $(106,131,136,156)$ in 2015 (RR $0.97,95 \%$ CI from 0.85 to 1.12 ). Two studies evaluating the risk of developing "any allergy" following supplementation in the breastfeeding mother and infant $(136,175)$ did not report any benefit or harm (RR 1.02, 95\% CI 0.71-1.46) (13). The same conclusions were expressed by the other three papers $(34,108,151)$. However, Lundelin et al. (176) reported the longterm safety and efficacy of four different strains of probiotics: children receiving LGG perinatally alone or in combination with other strains (Bifidobacterium lactis Bb-12, Lactobacillus paracaseiST11, and Bifidobacterium longumBL999) had a lower risk of developing allergic diseases (allergic rhinitis, eczema, asthma or food allergy) during long-term follow-up (at the age of at least 10 years) compared to the placebo group ( $47 \mathrm{vs.56 \% ,p}$ $=0.09)(176)$.

A positive effect was also demonstrated in a different RCT (125), involving 220 children (median age of 5 months) with CMA, randomized to either receive extensively hydrolyzed casein formula alone or with L. rhamnosus GG. In the group supplemented with LGG, there was a decrease in the incidence of allergic manifestations (including asthma, eczema, and allergic rhino-conjunctivitis) over a 3-year period and an increased rate of acquisition of tolerance at 36 months (125).

In 2019 a meta-analysis (177) of 17 RCTs (5,264 children) reported there was no significant reduction in the risk of developing asthma after probiotic supplementation compared with controls (RR: $0.86,95 \%$ CI: $0.73-1.01 ; p=0.06$ ). However, through subgroup analyses, the occurrence of asthma was reduced by L-GG supplementation (RR 0.75; 95\% CI: 0.57-0.99; $p=0.04$ ) and post-natal only (compared to pre- and post-natal) intervention. The rate of AR, wheeze, and positive aeroallergen
SPT results were not different between the two groups. In conclusion, this meta-analysis underlined the importance of specific strain of probiotics and the timing of intervention but also the need for large-sample and high-quality RCTs (177).

Recently, Schmidt et al. (126) examined the effect of supplementation with a mixture of two probiotic strains (Lactobacillus rhamnosus and Bifidobacterium animalis subsp lactis) in late infancy and early childhood (the mean age at enrollment was 10 months) on the development of allergic diseases and sensitization. As part of the Probicomp Study (138), a double-blind, placebo-controlled intervention trial in which the primary outcome was to reduce infection rate, 290 participants were randomized to either receive a daily mixture of the two probiotic strains $(n=144)$ or placebo $(n=146)$ for 6 months, starting prior to attending daycare. At follow-up (mean age 16.1 months) there was a significantly decreased incidence of eczema in the probiotic group compared to the placebo group (4.2 vs. $11.5 \%, P=0.036$ ), corresponding to a relative risk of 0.37 , but no differences in the incidence of asthma, rhinitis, conjunctivitis, and sensitization across groups were noted (126). However, when the endpoint was grouped as "any allergic disease" (including eczema), $7.6 \%(n=9)$ in the probiotic group and $18.9 \%(n=$ $23)$ in the placebo group were affected $(P=0.010)(126)$.

Therefore, in conclusion, differences in environmental factors, such as diet or geographic region, in genetic liability as well as in probiotic strains used, timing, and duration of supplementation may be responsible for the heterogeneity in the results of different studies. Overall, diet supplementation with probiotics does not seems to have a beneficial effect in the prevention of allergic manifestations other than AD.

\section{SYNBIOTICS IN THE PREVENTION OF ALLERGIC DISEASES}

First of all, recently it has been revealed that breast milk is not sterile since contains live probiotic Lactobacillus (mostly salivarius and fermentum), Bifidobacterium species (B. breve) $(178,179)$ as well as Staphylococcus and Streptococcus. Many factors may influence the composition of breast milk microbiota: the composition of the mother's skin and intestinal microbiota, the mother's health state, and exposure to medications, mostly antibiotics. Moreover, we already discussed the presence and the role in human milk of non-digestible milk human oligosaccharides (HMO) (61). Therefore, we can consider breast milk as a natural synbiotic, containing both probiotics and prebiotics (180) and the beneficial effect of breast milk in the prevention of allergy could be associated with a "synbiotic's effect."

Regarding supplementation with synbiotics, there are only two RCTs evaluating their role to prevent AD or FA (Table 3A). The first study (156) reported a reduction in the rate of eczema and IgE-associated allergic diseases, including challenge-proven FA, by synbiotic supplementation. The second study documented a reduced eczema risk with synbiotic supplementation but did not study FA (181). However, a meta-analysis of these studies 
TABLE 3 | Synbiotics administration in prevention of allergic disorders.

(A) Synbiotic + Standard formula/breastfeeding.

\begin{tabular}{|c|c|c|c|c|c|c|c|c|c|}
\hline References & Study & Enrolled Patients & $\begin{array}{l}\text { Synbiotic }+ \\
\text { Standard formula/ breast } \\
\text { feeding }\end{array}$ & $\begin{array}{l}\text { Prebiotic substance, } \\
\text { Beginning of } \\
\text { Treatment (S), End of } \\
\text { Treatment (E). }\end{array}$ & $\begin{array}{l}\text { Probiotic Strain, } \\
\text { Beginning of } \\
\text { Treatment (S), End of } \\
\text { Treatment (E). }\end{array}$ & $\begin{array}{l}\text { Pre-natal } \\
\text { administration } \\
\text { (duration) }\end{array}$ & $\begin{array}{l}\text { Post-natal } \\
\text { 1administration } \\
\text { (duration) }\end{array}$ & Outcomes & $\begin{array}{l}\text { Follow-Up } \\
\text { (duration) }\end{array}$ \\
\hline $\begin{array}{l}\text { Kukkonen et al. } \\
\text { (156) }\end{array}$ & $\begin{array}{l}\text { double-blind } \\
\text { randomized, } \\
\text { placebo } \\
\text { controlled trial }\end{array}$ & $\begin{array}{l}-1223 \text { pregnant } \\
\text { woman carrying } \\
\text { high- risk } \\
\text { children and } \\
\text { their infants: } \\
-N=461 \\
\text { mothers-infants } \\
\text { received } \\
\text { symbiotic } \\
-N=464 \\
\text { mothers-infants } \\
\text { received placebo }\end{array}$ & $\begin{array}{l}\text { - Synbiotics group: } \\
\text { - mothers: } 1 \text { capsule } \\
\text { containing } 4 \text { probotics } \\
\text { twice daily } \\
\text { - infants received } 1 \text { opened } \\
\text { capsule containing the } \\
\text { same probiotics mixed with } \\
\text { galacto-oligosaccharides } \\
\text { once daily } \\
\text { Placebo group: capsules } \\
\text { containing microcrystalline } \\
\text { cellulose, and the infants } \\
\text { received syrup without } \\
\text { galacto-oligosaccharides }\end{array}$ & $\begin{array}{l}\text { Synbiotics group: } \\
\text { infants received } 1 \\
\text { opened capsule } \\
\text { containing the same } \\
\text { probiotics mixed with } \\
\text { drops of sugar syrup } \\
\text { containing } 0.8 \mathrm{~g} \text { of } \\
\text { galacto- } \\
\text { oligosaccharides once } \\
\text { daily } \\
\text { S(women): } 2-4 \text { weeks } \\
\text { before delivery } \\
\text { E (Women): at delivery } \\
\text { S (infants): birth } \\
\text { E (infants): } 6 \text { months }\end{array}$ & $\begin{array}{l}1 \text { capsule containing L. } \\
\text { rhamnosus GG(ATCC } \\
53103), 5 \times 10^{9} \mathrm{cfu} \text { L L. } \\
\text { LC705 (DSM 7061), } 5 \\
\times 10^{9} \mathrm{cfu} \text {; B. breve } \\
\text { Bb99(DSM 13692), } 2 \\
\times 10^{8} \mathrm{cfu} \text {; and P. } \\
\text { freudenreichii ssp. } \\
\text { shermanii JS(DSM } \\
7076), 2 \times 10^{9} \mathrm{cfu}, \\
\text { twice daily } \\
\text { S(women): } 2-4 \text { weeks } \\
\text { before delivery } \\
\text { E (Women): at delivery } \\
\text { S (infants): birth } \\
\text { E (infants): } 6 \text { months }\end{array}$ & $\begin{array}{l}\text { 2-4 weeks } \\
\text { before delivery }\end{array}$ & For 6 months & $\begin{array}{l}\text { There was no effect of } \\
\text { probiotic supplementation } \\
\text { compared with placebo on the } \\
\text { cumulative incidence of any } \\
\text { allergic disease (OR, 0.85; } \\
95 \% \mathrm{Cl} \text {, 0.64-1.12). } \\
\text { There was a reduced } \\
\text { occurrence of Eczema in the } \\
\text { probiotic group (OR, } 0.74 \text {; } \\
95 \% \mathrm{Cl} \text {, } 0.55-0.98)\end{array}$ & 2 years \\
\hline Roze et al. (181) & $\begin{array}{l}\text { double-blind, } \\
\text { randomized, } \\
\text { multicenter trial }\end{array}$ & $\begin{array}{l}\text { Ninety-seven } \\
\text { non-brestfed term } \\
\text { neonates: }\end{array}$ & $\begin{array}{l}\text { Symbiotics group (n 48): } \\
\text { Standard formula }+ \\
\text { symbiotics } \\
\text { Control group(n 49): } \\
\text { standard formula }\end{array}$ & $\begin{array}{l}\text { experimental formula } \\
\text { containing the two } \\
\text { strains of probiotics } \\
+96 \% \text { galacto- } \\
\text { oligosaccharides and } 4 \\
\% \text { short-chain } \\
\text { fructo-oligosaccharides }\end{array}$ & $\begin{array}{l}\text { experimental formula } \\
\text { containing L. } \\
\text { rhamnosus LCS- } \\
742\left(1.4 \times 10^{8}\right) \text {, B. } \\
\text { longum subsp infantis } \\
\text { M63 }\left(1.4 \times 10^{8}\right) \text { and } \\
\text { prebiotics: }\end{array}$ & no & For 6 months & $\begin{array}{l}\text { Atopic dermatitis was less } \\
\text { frequently observed in the } \\
\text { experimental group }(2.6 \% \text { vs. } \\
17.8 \%, P<0.05)\end{array}$ & 6 months \\
\hline \multicolumn{10}{|c|}{ (B) Synbiotic +Hydrolyzed/ amino acid-based formulas. } \\
\hline Refereences & Study & Enrolled patients & $\begin{array}{l}\text { Hydrolyzed/ amino } \\
\text { acid-based } \\
\text { formulas+synbiotic }\end{array}$ & $\begin{array}{l}\text { Prebiotic substance, } \\
\text { Beginning of } \\
\text { treatment (S), End of } \\
\text { treatment }(E) .\end{array}$ & $\begin{array}{l}\text { Probiotic strain, dose } \\
\text { Beginning of } \\
\text { treatment (S), End of } \\
\text { treatment }(E) .\end{array}$ & $\begin{array}{l}\text { Pre-natal } \\
\text { administra- } \\
\text { tion } \\
\text { (duration) }\end{array}$ & $\begin{array}{l}\text { Post-natal } \\
\text { administration } \\
\text { (duration) }\end{array}$ & Outcomes & $\begin{array}{l}\text { Follow-up } \\
\text { (duration) }\end{array}$ \\
\hline van der et al. (182) & $\begin{array}{l}\text { double-blind, } \\
\text { placebo- } \\
\text { controlled } \\
\text { multicentre trial }\end{array}$ & $\begin{array}{l}\text { ninety full-term } \\
\text { infants, aged }<7 \\
\text { months with } A D\end{array}$ & $\begin{array}{l}\text { Synbiotic group: extensively } \\
\text { hydrolyzed whey-based } \\
\text { formula with additional } \\
\text { synbiotics [B. breve M- } 16 \mathrm{~V} \\
\text { and a } \\
\text { galacto/fructooligosaccharide } \\
\text { mixture] } \\
\text { Control group: same formula } \\
\text { without synbiotics }\end{array}$ & $\begin{array}{l}\text { mixture of } 90 \% \text { scGOS } \\
\text { and } 10 \% \mathrm{lcFOS} \\
0.8 \mathrm{~g} / 100 \mathrm{ml} \\
\mathrm{S}:<7 \mathrm{month} \\
\text { E: after } 12 \text { weeks } \\
\end{array}$ & $\begin{array}{l}\text { B. breve } \mathrm{M}-16 \mathrm{~V}(1.3 \times \\
\left.10^{9} \mathrm{cfu} / 100 \mathrm{ml}\right) \\
\mathrm{S}:<7 \text { month } \\
\text { E: after } 12 \text { weeks }\end{array}$ & no & 12 weeks & $\begin{array}{l}\text { The SCORAD score } \\
\text { improvement (AD severity) did } \\
\text { not differ between the synbiotic } \\
\text { and the placebo group. In the } \\
\text { synbiotic group there was a } \\
\text { significantly higher percentage } \\
\text { of bifidobacteria }(54.7 \% \text { vs. } \\
30.1 \%, P<0.001 \text { ) and } \\
\text { significantly lower percentages } \\
\text { of Clostridium lituseburense }\end{array}$ & 12 weeks \\
\hline
\end{tabular}


TABLE 3 | Continued

\begin{tabular}{|c|c|c|c|c|c|c|c|c|c|}
\hline Refereences & Study & Enrolled patients & $\begin{array}{l}\text { Hydrolyzed/ amino } \\
\text { acid-based } \\
\text { formulas+synbiotic }\end{array}$ & $\begin{array}{l}\text { Prebiotic substance, } \\
\text { Beginning of } \\
\text { treatment }(\mathrm{S}) \text {, End of } \\
\text { treatment }(\mathrm{E}) \text {. }\end{array}$ & $\begin{array}{l}\text { Probiotic strain, dose } \\
\text { Beginning of } \\
\text { treatment (S), End of } \\
\text { treatment }(E) .\end{array}$ & $\begin{array}{l}\text { Pre-natal } \\
\text { administra- } \\
\text { tion } \\
\text { (duration) }\end{array}$ & $\begin{array}{l}\text { Post-natal } \\
\text { administration } \\
\text { (duration) }\end{array}$ & Outcomes & $\begin{array}{l}\text { Follow-up } \\
\text { (duration) }\end{array}$ \\
\hline & & & & & & & & $\begin{array}{l}\text { /Clostridium histolyticum ( } 0.5 \\
\text { vs. } 1.8, P=0.02 \text { ) and } \\
\text { Eubacterium rectale } \\
\text { /Clostridium coccoides ( } 7.5 \text { vs. } \\
38.1, P<0.001 \text { ) after } \\
\text { intervention than the placebo } \\
\text { group }\end{array}$ & \\
\hline van der et al. (183) & $\begin{array}{l}\text { double-blind, } \\
\text { placebo- } \\
\text { controlled } \\
\text { multicentre trial }\end{array}$ & $\begin{array}{l}\text { ninety full-term } \\
\text { infants, aged }<7 \\
\text { months with } A D\end{array}$ & $\begin{array}{l}\text { Synbiotic group: extensively } \\
\text { hydrolyzed whey-based } \\
\text { formula with additional } \\
\text { synbiotics [B. breve M- } 16 \mathrm{~V} \\
\text { and a } \\
\text { galacto/fructooligosaccharide } \\
\text { mixture] } \\
\text { Control group: same formula } \\
\text { without synbiotics }\end{array}$ & $\begin{array}{l}\text { mixture of } 90 \% \text { scGOS } \\
\text { and } 10 \% \mathrm{lcFOS} \\
0.8 \mathrm{~g} / 100 \mathrm{ml} \\
\mathrm{S}:<7 \mathrm{month} \\
\text { E: after } 12 \text { weeks } \\
\end{array}$ & $\begin{array}{l}\text { B. breve } \mathrm{M}-16 \mathrm{~V}(1.3 \times \\
\left.10^{9} \mathrm{cfu} / 100 \mathrm{ml}\right) \\
\mathrm{S}:<7 \text { month } \\
\text { E: after } 12 \text { weeks }\end{array}$ & no & 12 weeks & $\begin{array}{l}\text { infants in the synbiotics group } \\
\text { have a lower prevalence of } \\
\text { asthma-like symptoms } \\
\text { (frequent wheezing) and } \\
\text { asthma medication use at } \\
\text { 1-year follow-up than those } \\
\text { who received placebo [13.9\% } \\
\text { vs. } 34.2 \% \text {, absolute risk } \\
\text { reduction (ARR)] } 20.3 \% \text {, } 95 \% \\
\text { Cl }-39.2 \% \text { to }-1.5 \% \text { and } \\
(5.6 \% \text { vs. } 25.6 \% \text {, } \\
\text { ARR-20.1\%, } 95 \% \mathrm{Cl}-35.7 \% \\
\text { to }-4.5 \% \text { ) }\end{array}$ & 1 years \\
\hline Candy et al. (184) & $\begin{array}{l}\text { multicenter, } \\
\text { double-blind, } \\
\text { randomized } \\
\text { controlled trial }\end{array}$ & $\begin{array}{l}\text { Term infants }<13 \\
\text { months old, with } \\
\text { suspected } \\
\text { non-lgE-mediated } \\
\text { CMA }\end{array}$ & $\begin{array}{l}\text { Symbiotic group }(N=35) \text { : } \\
\text { amino-acid-based formula } \\
\text { (AAF) contained a prebiotic } \\
\text { blend and a probiotic strain } \\
\text { control group ( } N=36) \text { : } \\
\text { commercially available AAF }\end{array}$ & $\begin{array}{l}\text { chicory-derived neutral } \\
\text { oligofructose, } \\
\text { long-chain inulin }(9: 1 \\
\text { ratio at a total } \\
\text { concentration of } 0.63 \\
\mathrm{~g} / 100 \mathrm{ml} \\
\mathrm{S}:<13 \text { months } \\
\text { E: after } 8 \text { weeks }\end{array}$ & $\begin{array}{l}\text { Bifidobacterium breve } \\
\text { M-16V) at a } \\
\text { concentration of } 1.47 \\
\times 10^{9} \mathrm{CFU} / 100 \mathrm{~mL} \\
\mathrm{~S}:<13 \text { months } \\
\text { E: after } 8 \text { weeks }\end{array}$ & no & 8 weeks & $\begin{array}{l}\text { There was a significantly higher } \\
\text { median percentage of } \\
\text { Bifidobacteria w }(p<0.001) \text { in } \\
\text { the test group than in the } \\
\text { control subjects ( } 35.4 \% \text { vs. } \\
9.7 \%) \text {, whereas a lower } \\
\text { percentage of Eubacterium } \\
\text { rectale/Clostridium coccoides } \\
\text { group in feces ( } 9.5 \% \text { vs. } \\
24.2 \% \text { ) and similar to that } \\
\text { detected in breastfed infants } \\
\text { (55\% and } 6.5 \% \text {, respectively). } \\
\text { There was no statistically } \\
\text { significant changes over } 8 \\
\text { weeks in the reported scores } \\
\text { for skin symptoms. SCORAD } \\
\text { decreased between weeks } 0 \\
\text { and } 8, \text { from } 12.83 \pm 18.84 \text { to } \\
9.63 \pm 12.45 \text { in the test group } \\
\text { and from } 14.43 \pm 19.74 \text { to } \\
7.06 \pm 10.01 \text { in the control } \\
\text { group }\end{array}$ & 8 weeks \\
\hline
\end{tabular}




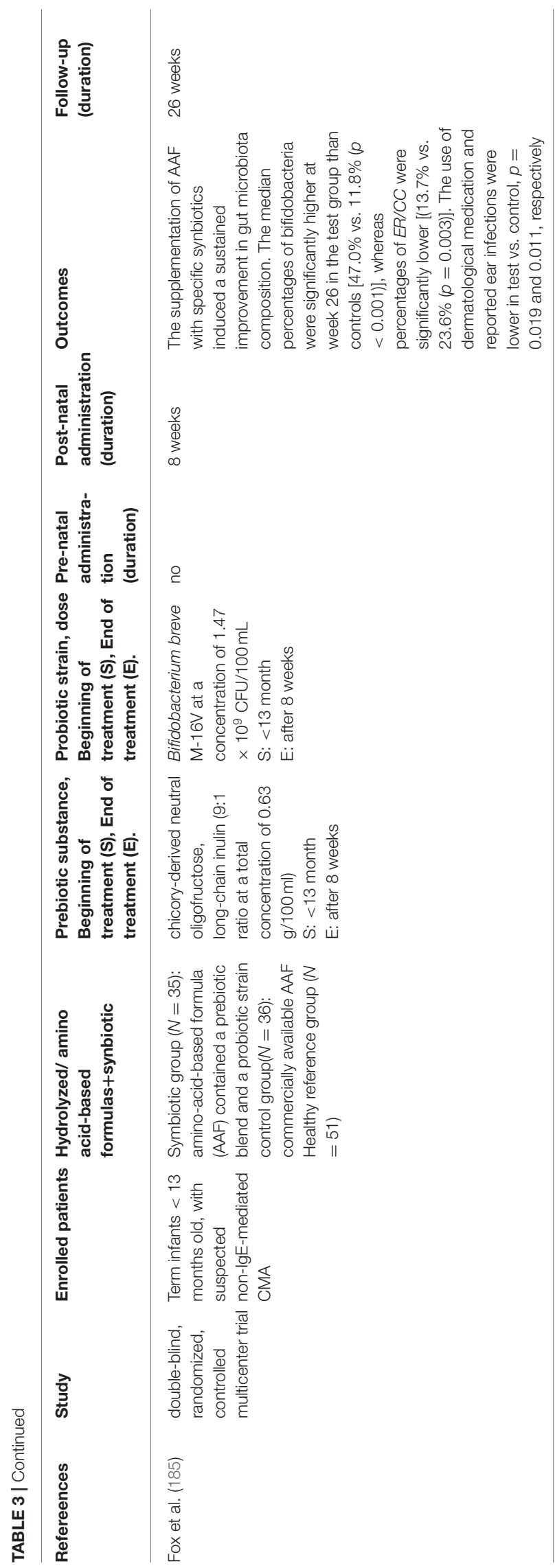

labeled these results as not significant, underling the wide CI (186).

Other studies evaluating synbiotic supplementation $(182,184$, 185 ) documented only fecal microbiota changes. Van der Aa et al. (182) reported the effects of a mixture of synbiotics, B. breve M-16V, and scGOS/lcFOS, added to an extensively hydrolyzed formula and administered for 3 months to formula-fed infants, in resembling the metabolic profile of breast-fed infants, by modulating the composition and the metabolic activity of gut microbiota. The same synbiotic mixture significantly reduced the prevalence of asthma-like symptoms and of asthma medications use at 1-year follow-up (183) (Table 3B). A recent multicenter double-blind RCT (184) documented the effects of an amino acid-based formula (AAF) supplemented with $B$. breve $\mathrm{M}-16 \mathrm{~V}$ and fructo-oligosaccharides, in 35 infants with suspected nonIgE-mediated CMA, compared to 36 controls: after 8 weeks of administration, there was a significantly lower median percentage of Bifidobacteria in the control group (9.7 vs. $35.4 \%$ ), whereas Eubacterium rectale/Clostridium coccoides group in feces was lower in the synbiotic group ( 9.5 vs. $24.2 \%$ ) and similar to breastfed infants (55 and 6.5\%, respectively). A subsequent trial with the same study groups and design and formulas confirmed the same changes in the fecal microbiota at 26 weeks (185).

Overall, the limited available data on the role of supplementation with synbiotics for the prevention of allergic diseases cannot allow a definitive conclusion.

\section{DISCUSSION}

Even if many studies, reviews, and meta-analyses, and several guidelines are available on this topic, the overall preventive effect of prebiotic/probiotic supplementation on allergic diseases remains unclear. The safety profile of these agents is excellent without significant adverse events in any revised literature. Regarding probiotics, the combined strategy of pre-natal and post-natal supplementation has been demonstrated promising in preventing atopic eczema; however, question when during the gestation and for how long the intervention should continue in the post-natal period is still open. There is no clear evidence that probiotics have a beneficial effect on the development of $\mathrm{AR}$, asthma, and/or wheezing. Thus, routine use of probiotics for preventive purposes cannot be recommended. Future studies focusing on the primary prevention of allergic diseases should investigate the optimal strains, dosing, duration of therapy, and longer follow-up times are warranted (170).

Currently, most guidelines, including those from the European Academy of Allergy and Clinical Immunology (169), and the European Society for Pediatric Gastroenterology, Hepatology, and Nutrition (98), due to lack of definitive evidence, do not recommend probiotic supplementation to prevent allergic diseases. Conversely, the World Allergy Organization (WAO), recommends probiotics for high-risk infants, for the potential benefits, in pregnant women, in breastfeeding women, and in infants, in preventing $\mathrm{AD}$ (10). However, the WAO did not consider specific strains and concluded that available data are not enough to support intervention for preventing any form 
of allergic disease by the routine use of probiotics, except for infants at high risk for eczema (10). Indeed, the activity of the probiotics is believed to depend on the bacterial strain type, on the dose, and on the intervention timing. Probiotics have been administered during pregnancy, lactation, to neonates, or later in infancy with different results, and without clear data on the right timing. Furthermore, careful selection of treatment strategy during pregnancy and early infancy is mandatory to identify the best target population, to achieve positive and limit negative outcomes.

The existing evidence on prebiotics is even more limited. The metanalyses and systematic reviews about prebiotics and prevention of allergic diseases concluded that the existing evidence is insufficient to draw conclusions $(96,98)$ on their preventive effect due to the high heterogeneity of the various studies. The WAO recommends supplementation with prebiotics in infants that are not exclusively breastfed, even if there is a very low quality of evidence (99). Cuello-Garcia et al. (100) showed a potential activity of prebiotic supplementation in infants resulting in asthma or wheezing risk reduction. However, the evidence is very low. The activity of prebiotics on the prevention of atopic eczema is observed, but data are inconclusive. Therefore, the authors (100) stated that available data on supplementation with prebiotics in terms of allergy risk reduction is not so strong to support or reject the concept of benefit or harm with prebiotic.

In addition, after a careful review of the available literature according to the method of administration (Tables 1-3), we noticed that the positive outcomes in prevention were reported more frequently among the group of studies in which prebiotics or probiotics were given with hydrolyzed/amino acid based formula, compared to those in which were administered alone or with a standard formula, suggesting a possible synergic effect with a hypoallergenic formula that needs to be confirmed with further studies. Moreover, due to the known bifidogenic effect of lactose, its content in different formulas (especially hydrolyzed/aminoacid based formulas) should be taking into

\section{REFERENCES}

1. Von Mutius E. The rising trends in asthma and allergic diseases. Clin Exp Allergy. (1998) 28:45-9. doi: 10.1046/j.1365-2222.1998.028s5045.x

2. Sicherer SH, Sampson HA. Food allergy: a review and update on epidemiology, pathogenesis, diagnosis, prevention, and management. J Allergy Clin Immunol. (2018) 141:41-8. doi: 10.1016/j.jaci.2017. 11.003

3. Prescott SL. Early-life environmental determinants of allergic diseases and the wider pandemic of inflammatory noncommunicable diseases. J Allergy Clin Immunol. (2013) 131:23-30. doi: 10.1016/j.jaci.2012.11.019

4. Ke X. Presence of multiple independent effects in risk loci of common complex human diseases. Am J Hum Genet. (2012) 91:185-92. doi: 10.1016/j.ajhg.2012.05.020

5. Moffatt MF, Gut IG, Demenais F, Strachan DP, Bouzigon E, Heath S, et al. A large-scale, consortium-based genomewide association study of asthma. $N$ Engl J Med. (2010) 363:1211-21. doi: 10.1056/NEJMoa0906312

6. Ober C, Yao TC. The genetics of asthma and allergic disease: a 21st century perspective. Immunol Rev. (2011) 242:10-30. doi: 10.1111/j.1600-065X.2011.01029.x account when evaluating the results of prebiotic studies, as might be a possible confounding factor. In addition, it has been recently suggested the possible role of different approaches to complementary feeding in the development of the gut microbiota in early life $(87,187,188)$. Therefore, the type of the first solid foods introduced could play a relevant role in shaping the infant's gut microbiota, as well as different intakes of foods naturally containing prebiotic components, all acting as possible confounding factors when evaluating results of pre/probiotic studies.

In conclusion, further RCTs in populations with high or low atopy risk, taking into account a possible synergic effect with other factors, are needed to carefully define the effectiveness of prebiotics/probiotics by itself for allergy prevention. At this time, on the basis of currently available data, supplementation with probiotics for prevention of allergies in children cannot be recommended, even if it is possible to underline the net benefit in high-risk infants in the prevention of eczema, as this effect is predominantly constant across studies available in the literature. However, the optimal strains, dose and timing, and duration of supplementation are still unknown, although a combined pre- and post-natal intervention appeared of stronger benefit. Moreover, the evidence for recommendation of prebiotic supplementation in infants who are not exclusively breastfed is of very low certainty and quality. Therefore, conclusive evidence is still lacking to be able to recommend routine use of pre/probiotics for allergic preventive purposes.

\section{AUTHOR CONTRIBUTIONS}

SSe, ED'A, and LP contributed to conception and design of the review, interpretation of data, drafting the article, and final approval of the version to be published. MB, SSa, VT, ES, FT, and DC contributed to interpretation of data, drafting the article, and final approval of the version to be published. All authors contributed to the article and approved the submitted version.

7. Lack G. Update on risk factors for food allergy. Allergy Clin Immunol. (2012) 129:1187-97. doi: 10.1016/j.jaci.2012.02.036

8. Paternoster L, Standl M, Chen CM, Ramasamy A, Bønnelykke K, Duijts $\mathrm{L}$, et al. Meta-analysis of genome-wide association studies identifies three new risk loci for atopic dermatitis. Nat Genet. (2012) 44:187-92. doi: $10.1038 /$ ng.1017

9. Heimall J, Spergel JM. Filaggrin mutations and atopy: consequences for future therapeutics. Expert Rev Clin Immunol. (2012) 8:189-97. doi: 10.1586/eci.11.100

10. Fiocchi A, Pawankar R, Cuello-Garcia C, Ahn K, Al-Hammadi S, Agarwal A, et al. World Allergy Organization-McMaster University Guidelines for Allergic Disease Prevention (GLAD-P): probiotics. World Allergy Organ J. (2015) 8:4. doi: 10.1186/s40413-015-0055-2

11. Prescott S, Allen KJ. Food allergy: riding the second wave of the allergy epidemic. Pediatr Allergy Immunol. (2011) 22:155-60. doi: 10.1111/j.1399-3038.2011.01145.x

12. Mitselou N, Hallberg J, Stephansson O, Almqvist C, Melén E, LudvigssonJF. Cesarean delivery, preterm birth, and risk of food allergy: NationwideSwedish cohort study of more than 1 million children. J Allergy ClinImmunol. (2018) 142:1510-14. doi: 10.1016/j.jaci.2018.06.044 
13. Kummeling I, Stelma FF, Dagnelie PC, Snijders BE, Penders J, HuberM, et al. Early life exposure to antibiotics and the subsequent development of eczema, wheeze, and allergic sensitization in the first 2 years of life: the KOALA Birth Cohort Study. Pediatrics. (2007) 119: e225-31. doi: 10.1542/peds.2006-0896

14. Wu GD, Chen J, Hoffmann C, Bittinger K, Chen YY, Keilbaugh SA, et al. Linking long-term dietary patterns with gut microbial enterotypes. Science. (2011) 334:105-8. doi: 10.1126/science.1208344

15. Trompette A, Gollwitzer ES, Yadava K, Sichelstiel AK, Sprenger N, NgomBru C, et al. Gut microbiota metabolism of dietary fiber influences allergic airway disease and hematopoiesis. Nat Med. (2014) 20:159-66. doi: $10.1038 / \mathrm{nm} .3444$

16. Jones AP, Tulic MK, Rueter K, Prescott SL. Vitamin D and allergic disease: sunlight at the end of the tunnel? Nutrients. (2012) 4:13-2. doi: $10.3390 /$ nu4010013

17. Sommer F, Backhed F. The gut microbiota-masters of host development and physiology. Nat Rev Microbiol. (2013) 11:227-38. doi: $10.1038 /$ nrmicro 2974

18. Harb H, Renz H. Update on epigenetics in allergic disease. J Allergy Clin Immunol. (2015) 135: 15-24. doi: 10.1016/j.jaci.2014.11.009

19. Berni Canani R, Paparo L, Nocerino R, Di Costanzo M, Cosenza L, Granata $\mathrm{V}$, et al. Gut microbiome as target for innovative strategies against food allergy. Front Immunol. (2019) 10:191. doi: 10.3389/fimmu.2019.00191

20. Bisgaard H, Li N, Bonnelykke K, Chawes BL, Skov T, Paludan-Muller G, et al. Reduced diversity of the intestinal microbiota during infancy is associated with increased risk of allergic disease at school age. J Allergy Clin Immunol. (2011) 128:646-52 doi: 10.1016/j.jaci.2011.04.060

21. Abrahamsson TR, Jakobsson HE, Andersson Bjorksten B, Engstrand L, Jenmalm MC. Low diversity of the gut microbiota in infants with atopic eczema. J Allergy Clin Immunol. (2012)129:434-40. doi: $10.1016 /$ j.jaci.2011.10.025

22. Abrahamsson TR, Jakobsson HE, Andersson AF, Bj€orksten B, Engstrand L, Jenmalm MC. Low gut microbiota diversity in early infancy precedes asthma at school age. Clin Exp Allergy. (2014) 44:842-50. doi: 10.1111/cea.12253

23. Ling Z, Li Z, Liu X, Cheng Y, Luo Y, Tong X, et al. Altered fecal microbiota composition associated with food allergy in infants. Appl Environ Microbiol. (2014) 80:2546-54. doi: 10.1128/AEM.00003-14

24. Kong HH, Oh J, Deming C, Conlan S, Grice EA, Beatson MA, et al. Temporal shifts in the skin microbiome associated with disease flares and treatment in children with atopic dermatitis. Genome Res. (2012) 22:850-9. doi: 10.1101/gr.131029.111

25. Kalliomäki M, Kirjavainen P, Eerola E, Kero P, Salminen S, Isolauri E. Distinct patterns of neonatal gut microflora in infants in whom atopy was and was not developing. J Allergy Clin Immunol. (2001) 107:129-34. doi: $10.1067 /$ mai.2001.111237

26. Sjögren YM, Jenmalm MC, Böttcher MF, Björkstén B, SverremarkEkström E. Altered early infant gut microbiota in children developing allergy up to 5 years of age. Clin Exp Allergy. (2009) 39:518-26. doi: $10.1111 /$ j.1365-2222.2008.03156.x

27. Penders J, Thijs C, van den Brandt PA, Kummeling I, Snijders B, Stelma F, et al. Gut microbiota composition and development of atopic manifestations in infancy: the KOALA Birth Cohort Study. Gut. (2007) 56:661-7. doi: 10.1136/gut.2006.100164

28. Cukrowska B. Microbial and nutritional programming-the importance of the microbiome and early exposure to potential food allergens in the development of allergies. Nutrients. (2018) 10:1541. doi: 10.3390/nu10101541

29. West CE, Renz H, Jenmalm MC, Kozyrskyj AL, Allen KJ, Vuillermin P, et al. The gut microbiota and inflammatory noncommunicable diseases: associations and potentials for gut microbiota therapies. J Allergy Clin Immunol. (2015)135:3-13. doi: 10.1016/j.jaci.2014.11.012

30. Perez-Muñoz ME, Arrieta MC, Ramer-Tait AE, Walter J. A critical assessment of the "sterile womb" and "in utero colonization" hypotheses: implications for research on the pioneer infant microbiome. Microbiome. (2017) 5:48. doi: 10.1186/s40168-017-0268-4

31. Panelli S, Schneider L, Comandatore F, Bandi C, Zuccotti GV, D’auria E. Is there life in the meconium? A challenging, burning question. Pharmacol Res. (2018) 137:148-9. doi: 10.1016/j.phrs.2018.10.005
32. Aagaard K, Ma J, Antony KM, Ganu R, Petrosino J, Versalovic J. The placenta harbors a unique microbiome. Sci Transl Med. (2014) 6:237. doi: 10.1126/scitranslmed.3008599

33. Cukrowska B, Bierła JB, Zakrzewska M, Klukowski M, Maciorkowska E. The relationship between the infant gut microbiota and allergy. The role of bifidobacterium breve and prebiotic oligosaccharides in the activation of anti-allergic mechanisms in early life. Nutrients. (2020) 12:946. doi: 10.3390/nu12040946

34. di Mauro G, Bernardini R, Barberi S, Capuano A, Correra A, de' Angelis GL, et al. Prevention of food and airway allergy: consensus of the Italian Society of Preventive and Social Paediatrics, the Italian Society of Paediatric Allergy and Immunology, and Italian Society of Pediatrics. World Allergy Organ J. (2016) 9:28. doi: 10.1186/s40413-016-0111-6

35. Isolauri E, Sutas Y, Kankaanpaa P, Arvilommi H, Salminen S. Probiotics: effects on immunity. Am J Clin Nutr. (2001) 73:444-50. doi: 10.1093/ajcn/73.2.444s

36. Fiocchi A, Burks W, Bahna SL, Bielory L, Boyle RJ, Cocco R, et al. Clinical use of probiotics in pediatric allergy (CUPPA): a world allergy organization position paper. World Allergy Organ J. (2012) 5:148-67. doi: 10.1097/WOX.0b013e3182784ee0

37. Gibson GR, Hutkins R, Sanders ME, Prescott SL, Reimer RA, Salminen SJ, et al. Expert consensus document: the International Scientific Association for Probiotics and Prebiotics (ISAPP) consensus statement on the definition and scope of prebiotics. Nat Rev Gastroenterol Hepatol. (2017) 14:491-502. doi: 10.1038/nrgastro.2017.75

38. Roberfroid M, Gibson GR, Hoyles L, McCartney AL, Rastall R, Rowland I, et al. Prebiotic effects: metabolic and health benefits. Br J Nutr. (2010) 104:1-63. doi: 10.1017/S0007114510003363

39. Björkstén B. Environmental influences on the development of the immune system: consequences for disease outcome. Nestle Nutr Workshop Ser Pediatr Program. (2008) 61:243-54. doi: 10.1159/000113498

40. Bawany F, Beck LA, Järvinen KM. Halting the march: primary prevention of atopic dermatitis and food allergies. J Allergy Clin Immunol Pract. (2020) 8:860-75. doi: 10.1016/j.jaip.2019.12.005

41. Li M, Wang M, Donovan SM. Early development of the gut microbiome and immune-mediated childhood disorders. Semin Reprod Med. (2014) 32:74-86. doi: 10.1055/s-0033-1361825

42. Arrieta MC, Stiemsma LT, Amenyogbe N, Brown EM, Finlay B. The intestinal microbiome in early life: health and disease. Front Immunol. (2014) 5:427. doi: 10.3389/fimmu.2014.00427

43. Ellwood P, Asher MI, Garcia-Marcos L, Williams H, Keil U, Robertson C, et al. Do fast foods cause asthma, rhinoconjunctivitis and eczema? Global findings from the International Study of Asthma and Allergies in Childhood (ISAAC). phase three. Thorax. (2013) 68:351-60. doi: 10.1136/thoraxjnl-2012-202285

44. First ISAPP Annual Meeting Report. Available online at: http://isappscience. org/annual-meeting-reports/ (accessed May 1, 2016).

45. Goldsmith JR, Sartor RB. The role of diet on intestinal microbiota metabolism: downstream impacts on host immune function and health, and therapeutic implications. J Gastroenterol. (2014) 49:785-98. doi: 10.1007/s00535-014-0953-z

46. Gibson GR, Probert HM, Loo JV, Rastall RA, Roberfroid MB. Dietary modulation of the human colonic microbiota: updating the concept of prebiotics. Nutr Res Rev. (2004) 17:259-75. doi: 10.1079/NRR200479

47. Scott KP, Gratz SW, Sheridan PO, Flint HJ, Duncan SH. The influence of diet on the gut microbiota. Pharmacol Res. (2013) 69:52-60. doi: 10.1016/j.phrs.2012.10.020

48. Austin S, De Castro CA, Bénet T, Hou Y, Sun H, Thakkar SK, et al. Temporal change of the content of 10 oligosaccharides in the milk of Chinese urban mothers. Nutrients. (2016) 8:346. doi: 10.3390/nu8060346

49. Xu G, Davis JC, Goonatilleke E, Smilowitz JT, German JB, Lebrilla CB. Absolute quantitation of human milk oligosaccharides reveals phenotypic variations during lactation. J Nutr. (2017) 147:117-24. doi: $10.3945 /$ jn.116.238279

50. Alderete TL, Autran C. Associations between human milk oligosaccharides and infant body composition in the first 6 mo of life. Am J Clin Nutr. (2015) 102:1381-8. doi: 10.3945/ajcn.115.115451 
51. Bode L, Contractor N. Overcoming the limited availability of human milk oligosaccharides: challenges and opportunities for research and application. Nutr Rev. (2016) 74:635-44. doi: 10.1093/nutrit/nuw025

52. Vandenplas Y. Prevention and management of cow's milk allergy in non-exclusively breastfed infants. Nutrients. (2017) 9:731. doi: 10.3390/nu9070731

53. Baldassarre ME, Bellantuono L, Mastromarino P, Miccheli A, Fanelli M, Laforgia N. Gut and breast milk microbiota and their role in the development of the immune function. Curr Pediatr Rep. (2014) 2:218-26. doi: 10.1007/s40124-014-0051-y

54. Seppo AE, Autran CA. Human milk oligosaccharides and development of cow's milk allergy in infants. J Allergy Clin Immunol. (2017) 139:708-11. doi: 10.1016/j.jaci.2016.08.031

55. Kim JH. Role of breast-feeding in the development of atopic dermatitis in early childhood. Allergy Asthma Immunol Res. (2017) 9:285-7. doi: 10.4168/aair.2017.9.4.285

56. Bergmann RL, Diepgen TL, Kuss O, Bergmann KE, Kujat J, Dudenhausen JW, et al. Breastfeeding duration is a risk factor for atopic eczema. Clin Exp Allergy. (2002) 32:205-9. doi: 10.1046/j.1365-2222.2002.01274.x

57. Pesonen M, Kallio MJ, Ranki A, Siimes MA. Prolonged exclusive breastfeeding is associated with increased atopic dermatitis: a prospective follow-up study of unselected healthy newborns from birth to age 20 years. Clin Exp Allergy. (2006) 36:1011-8. doi: 10.1111/j.1365-2222.2006.02526.x

58. Giwercman C, Halkjaer LB, Jensen SM, Bønnelykke K, Lauritzen L, Bisgaard $\mathrm{H}$. Increased risk of eczema but reduced risk of early wheezy disorder from exclusive breast-feeding in high-risk infants. J Allergy Clin Immunol. (2010) 125:866-71. doi: 10.1016/j.jaci.2010.01.026

59. Lodge CJ, Tan DJ, Lau MXZ, Dai X, Tham R, Lowe AJ, et al. Breastfeeding and asthma and allergies: a systematic review and meta-analysis. Acta Paediatr. (2015)104:38-53. doi: 10.1111/apa.13132

60. Verhasselt V. Oral tolerance in neonates: from basics to potential prevention of allergic disease. Mucosal Immunol. (2010) 3:326-33. doi: $10.1038 / \mathrm{mi} .2010 .25$

61. Oozeer R, van Limpt K, Ludwig T, Ben Amor K, Martin R, Wind RD, et al. Intestinal microbiology in early life: specific prebiotics can have similar functionalities as human-milk oligosaccharides. Am J Nutr. (2013) 98:56171. doi: 10.3945/ajcn.112.038893

62. Moro G, Minoli I, Mosca M, Fanaro S, Jelinek J, Stahl B, et al. Dosage related bifidogenic effects of galacto and fructo oligosaccharides in formula fed term infants. J Pediatr Gastroenterol Nutr. (2002) 34:291-5. doi: 10.1097/00005176-200203000-00014

63. Knol J, Scholtens B, Kafka C, Steenbakkers J, Gro S, Helm K, et al. Colon microflora in infant fed formula with galacto- and fructooligosaccharides: more like breast fed infants. J Pediatr Gastroenterol Nutr. (2005) 40:36-42. doi: 10.1097/00005176-200501000-00007

64. Rinne MM, Gueimonde M, Kalliomaki M, Hoppu U, Salminen SJ, Isolauri E. Similar bifidogenic effects of prebiotic-supplemented partially hydrolyzed infant formula and breastfeeding on infant gut microbiota. FEMS Immunol Med Microbiol. (2005) 43:59-65. doi: 10.1016/j.femsim.2004.07.005

65. Tanabe S, Hochi S. Oral administration of a galactooligosaccharide preparation inhibits development of atopic dermatitis-like skin lesions in NC/Nga mice. Int J Mol Med. (2010) 25:331-6. doi: 10.3892/ijmm_00000349

66. Schouten B, Van Esch BC, Kormelink TG, Moro GE, Arslanoglu S, Boehm $\mathrm{G}$, et al. Nondigestible oligosaccharides reduce immunoglobulin free lightchain concentrations in infants at risk for allergy. Pediatr Allergy Immunol. (2011) 22:537-42. doi: 10.1111/j.1399-3038.2010.01132.x

67. Ozdemir O. Prebiotics and probiotics in allergy: potential mechanisms of prebiotics' and probiotics' actions in allergy -(part 1). MOJ Immunol. (2016) 3:00069. doi: 10.15406/moji.2015.02.00069

68. Wahn U. Strategies for atopy prevention. J Nutr. (2008) 138:1770-2. doi: $10.1093 /$ jn/138.9.1770S

69. Ling EM, Smith T, Nguyen XD, Pridgeon C, Dallman M, Arbery J, et al. Relation of CD4+CD25+ regulatory T-cell suppression of allergen-driven T-cell activation to atopic status and expression of allergic disease. Lancet. (2004) 363:608-15. doi: 10.1016/S0140-6736(04)15592-X

70. Ostman S, Rask C, Wold AE, Hultkrantz S, Telemo E. Impaired regulatory $\mathrm{T}$ cell function in germ-free mice. Eur J Immunol. (2006) 36:2336-46. doi: $10.1002 /$ eji.200535244
71. Feleszko W, Jaworska J, Rha RD, Steinhausen S, Avagyan A, Jaudszus A, et al. Probiotic-induced suppression of allergic sensitization and airway inflammation is associated with an increase of $\mathrm{T}$ regulatory-dependent mechanisms in a murine model of asthma. Clin Exp Allergy. (2007) 37:498505. doi: 10.1111/j.1365-2222.2006.02629.x

72. Nazir Y, Hussain SA, Abdul Hamid A, Song Y. Probiotics and their potential preventive and therapeutic role for cancer, high serum cholesterol, and allergic and HIV diseases. Biomed Res Int. (2018) 29:3428437. doi: 10.1155/2018/3428437

73. Malin M, Verronen P, Korhonen H, Syväoja EL, Salminen S, Mykkänen H, et al. Dietary therapy with Lactobacillus GG, bovine colostrum or bovine immune colostrum in patients with juvenile chronic arthritis: evaluation of effect on gut defence mechanisms. Inflammopharmacology. (1997) 5:219-36. doi: 10.1007/s10787-997-0001-1

74. Özdemir Ö. Various effects of different probiotic strains in allergic disorders: an update from laboratory and clinical data. Clin Exp Immunol. (2010) 160:295-304. doi: 10.1111/j.1365-2249.2010.04109.x

75. Peng Y, Li A, Yu L, Qin G. The role of probiotics in prevention and treatment for patients with allergic rhinitis: a systematic review. Am J Rhinol Allergy. (2015) 29:292-8. doi: 10.2500/ajra.2015.29.4192

76. Niers LE, Hoekstra MO, Timmerman HM, van Uden NO, de Graaf PMA, Smits $\mathrm{HH}$, et al. Selection of probiotic bacteria for prevention of allergic diseases: immunomodulation of neonatal dendritic cells. Clin Exp Immunol. (2007) 149:344-52. doi: 10.1111/j.1365-2249.2007.03421.x

77. Kuitunen M. Probiotics and prebiotics in preventing food allergy and eczema. Curr Opin Allergy Clin Immunol. (2013) 13:280-6. doi: 10.1097/ACI.0b013e328360ed66

78. Baldassarre ME, Di Mauro A, Mastromarino P, Fanelli M, Martinelli D, Urbano F, et al. Administration of a multi-strain probiotic product to women in the perinatal period differentially affects the breast milk cytokine profile and may have beneficial effects on neonatal gastrointestinal functional symptoms. a randomized clinical trial. Nutrients. (2016) 8:677. doi: 10.3390/nu8110677

79. Salvatore S, Pensabene L, Borrelli O, Saps M, Thapar N, Concolino D, et al. Mind the gut: probiotics in paediatric neurogastroenterology. Benef Microbes. (2018) 10:1-16. doi: 10.3920/BM2018.0013

80. Moro G, Arslanoglu S. A mixture of prebiotic oligosaccharides reduces the incidence of atopic dermatitis during the first six months of age. Arch Dis Child. (2006) 91:814-9. doi: 10.1136/adc.2006.098251

81. D’Auria E, Salvatore S, Pozzi E, Mantegazza C, Sartorio M, Pensabene L, et al. Cow's milk allergy: immunomodulation by dietary intervention. Nutrients. (2019) 11:1399. doi: 10.3390/nu11061399

82. Ziegler E, Vanderhoof JA, Petschow B, Mitmesser SH, Stolz SI, Harris CL, et al. Term infants fed formula supplemented with selected blends of prebiotics grow normally and have soft stools similar to those reported for breast-fed infants. J Pediatr Gastroenterol Nutr. (2007) 44:359-64. doi: 10.1097/MPG.0b013e31802fca8c

83. Niele N, van Zwol A, Westerbeek EA, Lafeber HN, van Elburg RM. Effect of non-human neutral and acidic oligosaccharides on allergic and infectious diseases in preterm infants. Eur J Pediatr. (2013) 172:317-23. doi: 10.1007/s00431-012-1886-2

84. Grüber C, van Stuijvenberg M, Mosca F, Moro G, Chirico G, Braegger CP, et al. MIPS 1 Working Group. Reduced occurrence of early atopic dermatitis because of immunoactive prebiotics among low-atopy-risk infants. J Allergy Clin Immunol. (2010) 126:791-7. doi: 10.1016/j.jaci.2010.07.022

85. Gruber C, van Stuivenberg M, Mosca F, Moro G, Chirico G, Braegger CP, et al. Immunoactive prebiotics transiently prevent occurrence of early atopic dermatitis among low-atopy-risk infants. J Allergy Clin Immunol. (2015) 136:1696-8. doi: 10.1016/j.jaci.2015.07.049

86. Pontes MV, Ribeiro TC, Ribeiro H, de Mattos AP, Almeida IR, Leal VM, et al. Cow's milk-based beverage consumption in 1- to 4year-olds and allergic manifestations: an RCT. Nutr J. (2016) 15:19. doi: 10.1186/s12937-016-0138-0

87. Ranucci G, Buccigrossi V, Borgia E, Piacentini D, Visentin F, Cantarutti $\mathrm{L}$, et al. Galacto-oligosaccharide/polidextrose enriched formula protects against respiratory infections in infants at high risk of atopy: a randomized clinical trial. Nutrients. (2018) 10:E286. doi: 10.3390/nu100 30286 
88. Arslanoglu S, Moro GE, Schmitt J, Tandoi L, Rizzardi S, Boehm G. Early dietary intervention with a mixture of prebiotic oligosaccharides reduces the incidence of allergic manifestations and infections during the first two years of life. J Nutr. (2008) 138:1091-5. doi: 10.1093/jn/138. 6.1091

89. Arslanoglu S, Moro GE, Boehm G, Wienz F, Stahl B, Bertino E. Early neutral prebiotic oligosaccharide supplementation reduces the incidence of some allergic manifestations in the first 5 years of life. J Biol Regul Homeost Agents. (2012) 26:49-59.

90. Francavilla R, Calasso M. Effect of lactose on gut microbiota and metabolome of infants with cow's milk allergy. Pediatr Allergy Immunol. (2012) 23:420-7. doi: 10.1111/j.1399-3038.2012.01286.x

91. Boyle RJ, Tang ML, Chiang WC, Chua MC, Ismail I, Nauta A, et al. PATCH study investigators. Prebiotic-supplemented partially hydrolysed cow's milk formula for the prevention of eczema in high-risk infants: a randomized controlled trial. Allergy. (2016) 71:701-10. doi: 10.1111/all.12848

92. Wopereis $\mathrm{H}$, Sim K. Intestinal microbiota in infants at high risk for allergy: effects of prebiotics and role in eczema development. J Allergy Clin Immunol. (2018) 141:1334-42. doi: 10.1016/j.jaci.2017.05.054

93. Orel R, Reberšak LV. Clinical effects of prebiotics in pediatric population. Indian Pediatr. (2016) 53:1083-9.

94. Boehm G, Moro G. Structural and functional aspects of prebiotics used in infant nutrition. J Nutr. (2008) 138:1818-28. doi: 10.1093/jn/138.9.1818S

95. Reverri EJ, Devitt AA, Kajzer JA, Baggs GE, Borschel MW. Review of the clinical experiences of feeding infants formula containing the human milk oligosaccharide 2'-fucosyllactose. Nutrients. (2018) 10:1346. doi: 10.3390/nu10101346

96. Osborn DA, Sinn JK. Prebiotics in infants for prevention of allergy. Cochrane Database Syst Rev. (2013) 3:CD006474. doi: 10.1002/14651858.CD006474.pub3

97. Williams HC, Grindlay DJ. What's new in atopic eczema? An analysis of systematic reviews published in 2007 and 2008. Part 2. Disease prevention and treatment. Clin Exp Dermatol. (2010) 35:223-7. doi: 10.1111/j.1365-2230.2009.03734.x

98. Braegger C, Chmielewska A. Supplementation of infant formula with probiotics and/or prebiotics: a systematic review and comment by the ESPGHAN committee on nutrition. J Pediatr Gastroenterol Nutr. (2011) 52:238-50. doi: 10.1097/MPG.0b013e3181fb9e80

99. Cuello-Garcia CA, Fiocchi A, Pawankar R, Yepes-Nunez JJ, Morgano GP, Zhang Y, et al. World Allergy Organization-McMaster University Guidelines for Allergic Disease Prevention (GLAD-P): prebiotics. World Allergy Organ J. (2016) 9:10. doi: 10.1186/s40413-016-0102-7

100. Cuello-Garcia C, Fiocchi A, Pawankar R, Yepes-Nuñez JJ, Morgano GP, Zhang Y, et al. Prebiotics for the prevention of allergies: a systematic review and meta-analysis of randomized controlled trials. Clin Exp Allergy. (2017) 47:1468-77. doi: 10.1111/cea.13042

101. Doherty AM, Lodge CJ. Human milk oligosaccharides and associations with immune-mediated disease and infection in childhood: a systematic review. Front Pediatr. (2018) 6:91. doi: 10.3389/fped.2018.00091

102. Kleinjans L, Veening-Grioen DH. Mice co-administrated with partially hydrolysed whey proteins and prebiotic fibre mixtures show allergen-specific tolerance and a modulated gut microbiota. Benef Microbes. (2019) 10:165-78. doi: 10.3920/BM2018.0001

103. Forsberg A, West CE, Prescott SL, Jenmalm MC. Pre- and probiotics for allergy prevention: time to revisit recommendations? Clin Exp Allergy. (2016) 46:1506-21. doi: 10.1111/cea.12838

104. Matsuki T, Watanabe K, Tanaka R, Fukuda M, Oyaizu H. Distribution of bifidobacterial species in human intestinal microflora examined with $16 \mathrm{~S}$ rRNA-gene-targeted speciesspecific primers. Appl Environ Microbiol. (1999) 65:4506-12. doi: 10.1128/AEM.65.10.4506-4512.1999

105. West CE, Jenmalm MC, Prescott SL. The gut microbiota and its role in the development of allergic disease: a wider perspective. Clin Exp Allergy. (2015) 45:43-53. doi: 10.1111/cea.12332

106. Marschan E, Kuitunen M, Kukkonen K, Poussa T, Sarnesto A, Haahtela $\mathrm{T}$, et al. Probiotics in infancy induce protective immune profiles that are characteristic for chronic low-grade inflammation. Clin Exp Allergy. (2008) 38:611-8. doi: 10.1111/j.1365-2222.2008.0 2942.x
107. Frei R, Akdis M, O'Mahony L. Prebioitcs, probiotics, synbioitcs, and the immune system: experimental data and clinical evidence. Curr Opin Gastroenterol. (2015) 31:153-8. doi: 10.1097/MOG.0000000000000151

108. Cuello-Garcia CA, Brozek JL, Fiocchi A, Pawankar R, Yepes-Nunez JJ, Terracciano L, et al. Probiotics for the prevention of allergy: a systematic review and meta-analysis of randomized controlled trials. J Allergy Clin Immunol. (2015) 136:952-61. doi: 10.1016/j.jaci.2015.04.031

109. Kalliomaki M, Salminen S, Arvilommi H, Kero P, Koskinen P, Isolauri E. Probiotics in primary prevention of atopic disease: a randomized placebo-controlled trial. Lancet. (2001) 357:1076-9. doi: 10.1016/S0140-6736(00)04259-8

110. Marlow G, Han DY, Wickens K, Stanley T, Crane J, Mitchell EA, et al. Differential effects of two probiotics on the risks of eczema and atopy associated with single nucleotide polymorphisms to Toll-like receptors. Pediatr Allergy Immunol. (2015) 26:262-71. doi: 10.1111/pai.12371

111. Rautava S, Kalliomaki M, Isolauri E. Probiotics during pregnancy and breastfeeding might confer immunomodulatory protection against atopic disease in the infant. J Allergy Clin Immunol. (2002) 109:119-21. doi: $10.1067 /$ mai.2002.120273

112. Kalliomaki M, Salminen S, Poussa T, Arvilommi H, Isolauri E. Probiotics and prevention of atopic disease: 4-year follow-up of a randomised placebo-controlled trial. Lancet. (2003) 361:1869-71. doi: 10.1016/S0140-6736(03)13490-3

113. Kalliomaki M, Salminen S, Poussa T, Isolauri E. Probiotics during the first 7 years of life: a cumulative risk reduction of eczema in a randomized, placebo-controlled trial. J Allergy Clin Immunol. (2007) 119:1019-21. doi: $10.1016 /$ j.jaci.2006.12.608

114. Wickens K, Black PN, Stanley TV, Mitchell E, Fitzharris P, Tannock GW, et al. Probiotic Study Group. A differential effect of 2 probiotics in the prevention of eczema and atopy: a double-blind, randomized, placebo-controlled trial. $J$ Allergy Clin Immunol. (2008) 122:788-94. doi: 10.1016/j.jaci.2008.07.011

115. Dotterud CK, Storro O, Johnsen R, Oien T. Probiotics in pregnant women to prevent allergic disease: a randomized, double-blind trial. $\mathrm{Br} J$ Dermatol. (2010) 163:616-23. doi: 10.1111/j.1365-2133.2010.09889.x

116. Kim JY, Kwon JH, Ahn SH, Lee SI, Han YS, Choi YO, et al. Effect of probiotic mix (Bifidobacterium bifidum, Bifidobacterium lactis, Lactobacillus acidophilus) in the primary prevention of eczema: a double-blind, randomized, placebo-controlled trial. Pediatr Allergy Immunol. (2010) 21: 386-93. doi: 10.1111/j.1399-3038.2009.00958.x

117. West CE, Hammarstrom ML, Hernell O. Probiotics during weaning reduce the incidence of eczema. Pediatr Allergy Immunol. (2009) 20:430-7. doi: 10.1111/j.1399-3038.2009.00745.x

118. Lodinova-Zadnikova R, Prokesova L, Kocourkova I, Hrdy J, Zizka J. Prevention of allergy in infants of allergic mothers by probiotic Escherichia coli. Int Arch Allergy Immunol. (2010) 153:201-6. doi: 10.1159/000312638

119. Ezaki S, Itoh K, Kunikata T, Suzuki K, Sobajima H, Tamura M. Probiotics reduce cow's milk protein intolerance in neonates after small intestine surgery and antibiotic treatment presenting symptoms that mimics postoperative infection. Allergol Int. (2012) 61:107-13. doi: 10.2332/allergolint.11-OA-0305

120. Wickens K, Black P, Stanley TV, Mitchell E, Barthow C, Fitzharris P, et al. A protective effect of Lactobacillus rhamnosus HN001 against eczema in the first 2 years of life persists to age 4 years. Clin Exp Allergy. (2012) 42:1071-9. doi: 10.1111/j.1365-2222.2012.03975.x

121. Wickens K, Stanley TV, Mitchell E, Barthow C, Fitzharris P, Purdie G, et al. Early supplementation with Lactobacillus rhamnosus HN001 reduces eczema prevalence to 6 years: does it also reduce atopic sensitization? Clin Exp Allergy. (2013) 43:1048-57. doi: 10.1111/cea.12154

122. Wickens K, Barthow C, Mitchell EA, Kang J, van Zyl N, Purdie G, et al. Crane Effects of Lactobacillus rhamnosus HN001 in early life on the cumulative prevalence of allergic disease to 11 years. Pediatr Allergy Immunol. (2018) 29:1-7. doi: 10.1111/pai.12982

123. Bertelsen RG, Brantsæter AL, Magnus MC, Haugen M, Myhre R, Jacobsson $\mathrm{B}$, et al. Probiotic milk consumption in pregnancy and infancy and subsequent childhood allergic diseases. J Allergy Clin Immunol. (2014) 133:165-171. doi: 10.1016/j.jaci.2013.07.032

124. Simpson MR, Dotterud CK, Storrø O, Johnsen R, Øien T. Perinatal probiotic supplementation in the prevention of allergy related disease: 6 year 
follow up of a randomised controlled trial. BMC Dermatol. (2015) 15:13. doi: 10.1186/s12895-015-0030-1

125. Berni Canani R, Di Costanzo M, Bedogni G, Amoroso A, Cosenza L, Di Scala, et al. Extensively hydrolyzed casein formula containing Lactobacillus rhamnosus GG reduces the occurrence of other allergic manifestations in children with cow's milk allergy: 3-year randomized controlled trial. J Allergy Clin Immunol. (2017) 139:1906-13. doi: 10.1016/j.jaci.2016.10.050

126. Schmidt RM, Pilmann Laursen R, Bruun S, Larnkjaer A, Mølgaard C, Michaelsen KF, et al. Probiotics in late infancy reduce the incidence of eczema: a randomized controlled trial. Pediatr Allergy Immunol. (2019) 30:335-40. doi: 10.1111/pai.13018

127. Peldan P, Kukkonen AK, Savilahti E, Kuitunen M. Perinatal probiotics decreased eczema up to 10 years of age, but at 5-10 years, allergic rhino-conjunctivitis was increased. Clin Exp Allergy. (2017) 47:975-9. doi: 10.1111/cea.12924

128. Taylor AL, Dunstan JA, Prescott SL. Probiotic supplementation for the first 6 months of life fails to reduce the risk of atopic dermatitis and increases the risk of allergen sensitization in high-risk children: a randomized controlled trial. J Allergy Clin Immunol. (2007) 119:184-91. doi: 10.1016/j.jaci.2006.08.036

129. Abrahamsson TR, Jakobsson T, Fageras Bottcher M, Fredrikson M, Jenmalm MC, Björkstén B, et al. Probiotics in prevention of IgE-associated eczema: a double-blind, randomized, placebo-controlled trial. J Allergy Clin Immunol. (2007)119:1174-80. doi: 10.1016/j.jaci.2007.01.007

130. Kopp MV, Hennemuth I, Heinzmann A, Urbanek R. Randomized, doubleblind, placebo controlled trial of probiotics for primary prevention: no clinical effects of Lactobacillus GG supplementation. Pediatrics. (2008) 121:850-6. doi: 10.1542/peds.2007-1492

131. Prescott SL, Wiltschut J, Taylor A, Westcott L, Jung W, Currie H, et al. Early markers of allergic disease in a primary prevention study using probiotics: 2.5-year follow-up phase. Allergy. (2008) 63:1481-90. doi: 10.1111/j.1398-9995.2008.01778.x

132. Kopp MV, Salfeld P. Probiotics and prevention of allergic disease. Curr Opin Clin Nutr Metab Care. (2009)12:298-303. doi: 10.1097/MCO.0b013e32832989a3

133. Kuitunen M, Kukkonen K, Juntunen-Backman K, Korpela R, Poussa T, Tuure T, et al. Probiotics prevent IgE-associated allergy until age 5 years in cesareandelivered children but not in the total cohort. J Allergy Clin Immunol. (2009)123:335-41. doi: 10.1016/j.jaci.2008.11.019

134. Niers L, Martin R, Rijkers G, Sengers F, Timmerman H, van Uden $\mathrm{N}$, et al. The effects of selected probiotic strains on the development of eczema (the PandA study). Allergy. (2009) 64:1349-58. doi: 10.1111/j.1398-9995.2009.02021.x

135. Boyle RJ, Ismail IH, Kivivuori S, Licciardi PV, Robins-Browne RM, Mah LJ, et al. Lactobacillus GG treatment during pregnancy for the prevention of eczema: a randomized controlled trial. Allergy. (2011) 66:509-16. doi: 10.1111/j.1398-9995.2010.02507.x

136. Ou CY, Kuo HC, Wang L, Hsu TY, Chuang H, Liu CA. Prenatal and postnatal probiotics reduces maternal but not childhood allergic diseases: a randomized, double-blind, placebo-controlled trial. Clin Exp Allergy. (2012) 42:1386-96. doi: 10.1111/j.1365-2222.2012.04037.x

137. Damm JA, Smith B, Greisen G, Krogfelt KA, Clausen ML, Agner T. The influence of probiotics for preterm neonates on the incidence of atopic dermatitis-results from a historically controlled cohort study. Arch Dermatol Res. (2017) 309:259-64. doi: 10.1007/s00403-017-1725-4

138. Laursen RP, Larnkjaer A, Ritz C, Hauger H, Michaelsen KF, Mølgaard C. Probiotics and child care absence due to infections: a randomized controlled trial. Pediatrics. (2017) 140:e20170735. doi: 10.1542/peds.2017-0735

139. Murphy R, Morgan XC, Wang XY, Wickens K, Purdie G, Fitzharris P, et al. Eczema-protective probiotic alters infant gut microbiome functional capacity but not composition: sub-sample analysis from a RCT. Benef Microbes. (2019) 10:5-17. doi: 10.3920/BM2017.0191

140. Osborn DA, Sinn JK. Probiotics in infants for prevention of allergic disease and food hypersensitivity. Cochrane Database Syst Rev. (2007) 4:CD006475. doi: 10.1002/14651858.CD006475.pub2

141. Foisy M, Boyle RJ, Chalmers JR, Simpson EL, Williams HC. Overview of reviews the prevention of eczema in infants and children: an overview of Cochrane and non-Cochrane reviews. Evid Based Child Health. (2011) 6:1322-39. doi: 10.1002/ebch.827

142. Lee J, Seto D, Bielory L. Meta-analysis of clinical trials of probiotics for prevention and treatment of pediatric atopic dermatitis. J Allergy Clin Immunol. (2008) 121:116-21. doi: 10.1016/j.jaci.2007.10.043

143. Betsi GI, Papadavid E, Falagas ME. Probiotics for the treatment or prevention of atopic dermatitis: a review of the evidence from randomised controlled trials. Am J Clin Dermatol. (2008) 9:93-103. doi: 10.2165/00128071-200809020-00002

144. Doege K, Grajecki D, Zyriax BC, Detinkina E, Eulenburg CZ, Buhling KJ. Impact of maternal supplementation with probiotics during pregnancy on atopic eczema in childhood-a meta-analysis. Br J Nutr. (2012) 107:1-6. doi: $10.1017 /$ S0007114511003400

145. Pelucchi C, Chatenoud L, Turati F, Galeone C, Moja L, Bach JF, et al. Probiotics supplementation during pregnancy or infancy for the prevention of atopic dermatitis: a metaanalysis. Epidemiology. (2012) 23:402-14. doi: 10.1097/EDE.0b013e31824d5da2

146. Foolad N, Brezinski EA, Chase EP, Armstrong AW. Effect of nutrient supplementation on atopic dermatitis in children: a systematic review of probiotics, prebiotics, formula, and fatty acids. JAMA Dermatol. (2013) 149:350-5. doi: 10.1001/jamadermatol.2013.1495

147. Hascoet JM, Hubert C, Rochat F, Legagneur H, Gaga S, EmadyAzar S, et al. Effect of formula composition on the development of infant gut microbiota. J Pediatr Gastroenterol Nutr. (2011) 52:756-62. doi: 10.1097/MPG.0b013e3182105850

148. Soh SE, Aw M, Gerez I, Chong YS, Rauff M, Ng YP, et al. Probiotic supplementation in the first 6 months of life in at risk Asian infants-effects on eczema and atopic sensitization at the age of 1 year. Clin Exp Allergy. (2009) 39:571-8. doi: 10.1111/j.1365-2222.2008.03133.x

149. Taylor AL, Hale J, Hales BJ, Dunstan JA, Thomas WR, Prescott SL. FOXP3 mRNA expression at 6 months of age is higher in infants who develop atopic dermatitis, but is not affected by giving probiotics from birth. Pediatr Allergy Immunol. (2007) 18:10-9. doi: 10.1111/j.1399-3038.2006.00483.x

150. Morisset M, Aubert-Jacquin C, Soulaines P, Moneret-Vautrin DA, Dupont C. A non-hydrolyzed, fermented milk formula reduces digestive and respiratory events in infants at high risk of allergy. Eur J Clin Nutr. (2011) 65:175-83. doi: $10.1038 /$ ejen.2010.250

151. Zuccotti G, Meneghin F, Aceti A, Barone G, Callegari ML, Di Mauro A, et al. Italian Society of Neonatology. Probiotics for prevention of atopic diseases in infants: systematic review and meta-analysis. Allergy. (2015) 70:1356-71. doi: $10.1111 /$ all.12700

152. West CE, Jenmalm MC, Kozyrskyj AL, Prescott SL. Probiotics for treatment and primary prevention of allergic diseases and asthma: looking back and moving forward. Exp Rev Clin Immunol. (2016) 12:625-39. doi: 10.1586/1744666X.2016

153. Li L, Han Z, Niu X, Zhang G, Jia Y, Zhang S, et al. Probiotic supplementation for prevention of atopic dermatitis in infants and children: a systematic review and meta-analysis. Am J Clin Dermatol. (2019) 20:36777. doi: 10.1007/s40257-018-0404-3

154. Mugambi MN, Musekiwa A, Lombard M, Young T, Blaauw R. Synbiotics, probiotics or prebiotics in infant formula for full term infants: a systematic review. Nutr J. (2012) 11:81. doi: 10.1186/1475-2891-11-81

155. Allen SJ, Jordan S, Storey M, Thornton CA, Gravenor MB, Garaiova I, et al. Probiotics and atopic ECZEMA: a double-blind randomised controlled trial. Arch Dis Child. (2012) 97:A2. doi: 10.1136/archdischild-2012-301885.5

156. Kukkonen K, Savilahti E, Haahtela T, Juntunen-Backman K, Korpela $\mathrm{R}$, Poussa $\mathrm{T}$, et al. Probiotics and prebiotic galacto-oligosaccharides in the prevention of allergic diseases: a randomized, double-blind, placebo-controlled trial. J Allergy Clin Immunol. (2007) 119:192-8. doi: 10.1016/j.jaci.2006.09.009

157. Cosenza L, Nocerino R, Di Scala C, di Costanzo M, Amoroso A, Leone L, et al. Bugs for atopy: the Lactobacillus Rhamnosus GG strategy for food allergy prevention and treatment in children. Benef Microbes. (2015) 6:225-32. doi: 10.3920/BM2014.0158

158. Elazab N, Mendy A, Gasana J, Vieira ER, Quizon A, Forno E. Probiotic administration in early life, atopy, and asthma: a meta-analysis of clinical trials. Pediatrics. (2013) 132:666-76. doi: 10.1542/peds.2013-0246 
159. Kim SO, Ah YM, Yu YM, Choi KH, Shin WG, Lee JY. Effects of probiotics for the treatment of atopic dermatitis: a meta-analysis of randomized controlled trials. Ann Allergy Asthma Immunol. (2014) 113:21726. doi: 10.1016/j.anai.2014.05.021

160. Wang HT, Anvari S, Anagnostou K. The role of probiotics in preventing allergic disease. Children. (2019) 6:24. doi: 10.3390/children6020024

161. Azad MB, Coneys JG, Kozyrskyj AL, Field CJ, Ramsey CD, Becker AB, et al. Probiotic supplementation during pregnancy or infancy for the prevention of asthma and wheeze: systematic review and meta-analysis. BMJ. (2013) 347:f6471. doi: 10.1136/bmj.f6471

162. Cabana MD. No consistent evidence to date that prenatal or postnatal probiotic supplementation prevents childhood asthma and wheeze. Evid Based Med. (2014) 19:144. doi: 10.1136/eb-2014-101721

163. Kukkonen AK, Kuitunen M, Savilahti E, Pelkonen A, Malmberg P, Makela M. Airway inflammation in probiotic-treated children at 5 years. Pediatr Allergy Immunol. (2011) 22:249-51. doi: 10.1111/j.1399-3038.2010.01079.x

164. Isolauri E, Rautava S, Kalliomäki M, Kirjavainen P, Salminen S. Role of probiotics in food hypersensitivity. Curr Opin Allergy Clin Immunol. (2002) 2:263-71. doi: 10.1097/00130832-200206000-00018

165. Allen SJ, Jordan S, Storey M, Thornton CA, Gravenor MB, Garaiova I, et al. Probiotics in the prevention of eczema: a randomised controlled trial. Arch Dis Child. (2014) 99:1014-9. doi: 10.1136/archdischild-2013-305799

166. Koplin JJ, Peters RL, Allen KJ. Prevention of food allergies. Immunol Allergy Clin North Am. (2018) 38:1-11. doi: 10.1016/j.iac.2017.09.001

167. Cox MJ, Huang YJ, Fujimura KE, Liu JT, McKean M, Boushey $\mathrm{HA}$, et al. Lactobacillus casei abundance is associated with profound shifts in the infant gut microbiome. PLoS ONE. (2010) 5:e8745. doi: 10.1371/journal.pone.0008745

168. Kong Yang Y, Guan J, Wang R. Probiotics' preventive effect on pediatric food allergy: a meta-analysis of randomized controlled trials. Chin Med Sci J. (2014) 29:144-7. doi: 10.1016/S1001-9294(14)60059-6

169. Muraro A, Halken S, Arshad SH, EAACI Food Allergy and Anaphylaxis Guidelines Group, et al. EFACI food allergy and anaphylaxis guidelines. Primary prevention of food allergy. Allergy. (2014) 69:590-601. doi: 10.1111/all.12398

170. Zhang GQ, Hu HJ, Liu CY, Zhang Q, Shakya S, Li ZY. Probiotics for prevention of atopy and food hypersensitivity in early childhood: a PRISMA-compliant systematic review and meta-analysis of randomized controlled trials. Medicine. (2016) 95:e2562. doi: 10.1097/MD.00000000000 02562

171. Hol J, van Leer EH, Elink Schuurman BE, de Ruiter LF, Samsom JN, Hop $\mathrm{W}$, et al. The acquisition of tolerance toward cow's milk through probiotic supplementation: a randomized, controlled trial. J Allergy Clin Immunol. (2008) 121:1448-54. doi: 10.1016/j.jaci.2008.03.018

172. Berni Canani R, Nocerino R, Terrin G, Coruzzo A, Cosenza L, Leone L, et al. Effect of Lactobacillus GG on tolerance acquisition in infants with cow's milk allergy: a randomized trial. J Allergy Clin Immunol. (2012) 129:580-2. doi: 10.1016/j.jaci.2011.10.004

173. Pensabene L, Salvatore S, D'Auria E, Parisi F, Concolino D, Borrelli $\mathrm{O}$, et al.Cow's milk protein allergy in infancy: a risk factor for functional gastrointestinal disorders in children? Nutrients. (2018) 10:E1716. doi: $10.3390 /$ nu10111716

174. Rautava S, Arvilommi H, Isolauri E. Specific probiotics in enhancing maturation of IgA responses in formula-fed infants. Pediatr Res. (2006) 60:221-4. doi: 10.1203/01.pdr.0000228317.72 933.db

175. Ortiz-Andrellucchi A, Sanchez-Villegas A, Rodriguez-Gallego C, Lemes A, Molero T, Soria A, et al. Immunomodulatory effects of the intake of fermented milk with Lactobacillus casei DN114001 in lactating mothers and their children. Br J Nutr. (2008) 100:834-45. doi: 10.1017/S00071145089 59183
176. Lundelin K, Poussa T, Salminen S, Isolauri E. Long-term safety and efficacy of perinatal probiotic intervention: evidence from a follow-up study of four randomized, double-blind, placebo-controlled trials. Pediatr Allergy Immunol. (2017) 28:170-5. doi: 10.1111/pai.12675

177. Du X, Wang L, Wu S, Yuan L, Tang S, Xiang Y, et al. Efficacy of probiotic supplementary therapy for asthma, allergic rhinitis, and wheeze: a meta-analysis of randomized controlled trials. Allergy Asthma Proc. (2019) 40:250-60. doi: 10.2500/aap.2019.40.4227

178. Fernández L, Langa S, Martín V, Rogriguez JM. The microbiota of human milk in healthy women. Cell Mol. Biol. (2013) 59, 31-42.

179. Martín R, Jiménez E, Heilig H, Fernández L, Marín ML, Zoetendal EG et al. Isolation of bifidobacteria from breast milk and assessment of the bifidobacterial population by PCR-denaturing gradient gel electrophoresis and quantitative real-time PCR. Appl Environ Microbiol. (2009) 75:965-9. doi: 10.1128/AEM.02063-08

180. Jost T, Lacroix C, Braegger C, Chassard C. Impact of human milk bacteria and oligosaccharides on neonatal gut microbiota establishment and gut health. Nutr Rev. (2015) 73:426-37. doi: 10.1093/nutrit/nuu016

181. Roze JC, Barbarot S, Butel MJ, Kapel N, Waligora-Dupriet AJ, De Montgolfier I, et al. An alpha-lactalbumin-enriched and symbioticsupplemented v. a standard infant formula: a multicentre, double-blind, randomised trial. Br J Nutr. (2012) 107:1616-22. doi: 10.1017/S000711451100479X

182. Van Der Aa LB, Heymans HS, Van Aalderen WM, Sillevis Smitt JH, Knol J, Ben Amor K, et al. Effect of a new synbiotic mixture on atopic dermatitis in infants: a randomized-controlled trial. Clin Exp Allergy. (2010) 40:795-804. doi: 10.1111/j.1365-2222.2010.03465.x

183. van der Aa LB, van Aalderen WM, Heymans HS, Henk Sillevis Smitt J, Nauta AJ, Knippels LM, et al. Synbad Study Group. Synbiotics prevent asthmalike symptoms in infants with atopic dermatitis. Allergy. (2011) 66:170-7. doi: 10.1111/j.1398-9995.2010.02416.x

184. Candy DCA, Van Ampting MTJ. A synbiotic-containing amino-acid-based formula improves gut microbiota in non-IgE-mediated allergic infants. Pediatr Res. (2018) 83:677-86. doi: 10.1038/pr.2017.270

185. Fox AT, Wopereis H. A specific synbiotic-containing amino acidbased formula in dietary management of cow's milk allergy: a randomized controlled trial. Clin Transl Allergy. (2019) 9:5. doi: 10.1186/s13601-019-0241-3

186. Chang YS, Trivedi MK, Jha A, Lin YF, Dimaano L, Garcia-Romero MT. Synbiotics for prevention and treatment of atopic dermatitis: a metaanalysis of randomized clinical trials. JAMA Pediatr. (2016) 170:236-42. doi: 10.1001/jamapediatrics.2015.3943

187. D’Auria E, Bergamini M, Staiano A, Banderali G, Pendezza E, Penagini F et al. Baby-led weaning: what a systematic review of the literature adds on. Ital J Pediatr. (2018) 44:49. doi: 10.1186/s13052-018-0487-8

188. Krebs NF, Sherlock LG, Westcott J, Culbertson D, Hambidge KM, Feazel LM, et al. Effects of different complementary feeding regimens on iron status and enteric microbiota in breastfed infants. J Pediatr. (2013) 163:416-23. doi: 10.1016/j.jpeds.2013.01.024

Conflict of Interest: The authors declare that the research was conducted in the absence of any commercial or financial relationships that could be construed as a potential conflict of interest.

Copyright (c) 2020 Sestito, D'Auria, Baldassarre, Salvatore, Tallarico, Stefanelli, Tarsitano, Concolino and Pensabene. This is an open-access article distributed under the terms of the Creative Commons Attribution License (CC BY). The use, distribution or reproduction in other forums is permitted, provided the original author(s) and the copyright owner(s) are credited and that the original publication in this journal is cited, in accordance with accepted academic practice. No use, distribution or reproduction is permitted which does not comply with these terms. 